\title{
MEMBANGUN ETIKA DAN KEPRIBADIAN DI LEMBAGA PENDIDIKAN ISLAM: SEBUAH PERSPEKTIF PSIKOLOGI QUR'ANI
}

\author{
Ah. Zakki Fuad \\ (UIN Sunan Ampel Surabaya) \\ Jauharoti Alfin \\ (UIN Sunan Ampel Surabaya) \\ Ahmad Munjin Nasih \\ (Universitas Negeri Malang)
}

\begin{abstract}
Abstrak:
Lembaga pendidikan Islam mempunyai tanggung jawab yang besar dalam membangun etika dan kepribadian peserta didiknya. Tantangan pendidikan Islam sekarang ini adalah munculnya pergeseran tata nilai etika dan kepribadian di masyarakat karena pengaruh globalisasi, kemajuan teknologi, problematika sosial serta disparitas kemampuan ekonomi yang berbeda yang secara tidak langsung memunculkan konflik sosial, disharmonisasi hubungan orang tua dengan anak, guru dengan murid dan lain sebagainya. Al-Qur'an sebagai sumber penggalian keilmuan telah menawarkan konsep pembangunan etika dan kepribadian (ethics and personality development) bagi manusia, khususnya peserta didik di lembaga pendidikan melalui psikologi qur'ani. Konseptualisasi dan teorisasi psikologi qur'ani dalam tulisan ini menggunakan content analisis dengan langkah-langkah; Unitizing, Sampling, Recording, Reducing, Inferring, Anayzing and Narrating. Langkah-langkah metodologis ini akan menghasilkan konsep psikologi yang bersumber dari al-Qur'an dan dikombinasikan dengan beberapa teori psikologi; Connectionism theory, Classical Conditioning, Operant Coditioning, Contiguous Conditioning, Cogitive theory, Social Learning Theory. Hasilnya membangun rumusan bagaimana membangun etika dan kepribadian Qur'ani bagi peserta didik di Lembaga Pendidikan Islam.
\end{abstract}

Kata Kunci: Etika; Kepribadian; Psikologi; Al-Qur'an. 


\begin{abstract}
:
Islamic educational institutions have a great responsibility in building learners' ethics and personality. The challenge of Islamic education today is the emergence of a shift in ethical and personality values in society due to the influence of globalization, technological advancement, social problems, and economic disparities, which indirectly bring about social conflicts, parents-children slack relationships, as well as teachers-students weak engagement. Al-Qur'an as a source of scientific exploration has offered the concept of ethical and personality development (human ethics and personality development), especially for learners in educational institutions through Quranic psychology. The conceptualization and theorization of Quranic psychology in this paper makes use of content analysis with the following step: Unitizing, Sampling, Recording, Reducing, Inferring, Analyzing, and Narrating. These methodological steps results in the psychological concept rooted in the Qur'an to combine with some modern psycological theories, including Connectionism theory, Classical Conditioning, Operant Coditioning, Contiguous Conditioning, Cogitive theory, and Social Learning Theory. The results construct a mechanism of how to build Quranic ethics and personality for learners in Islamic educational institutions.
\end{abstract}

\title{
Keywords: Ethics; Personality; Psychology; Al-Qur'an.
}

\section{A. Pendahuluan}

Etika dan kepribadian merupakan elemen penting bagi harmonisasi, kemajuan dan keberlangsungan kehidupan masyarakat suatu bangsa. Etika dan kepribadian mempunyai kedudukan yang penting karena berhubungan dengan perbuatan dan perilaku manusia yang mampu mengakibatkan hal-hal yang baik dan buruk dengan bantuan akal pikiran. ${ }^{1}$ Secara teori, etika dan kepribadian berhubungan dengan obyek, yaitu membahas perbuatan yang dilakukan manusia, berhubungan dengan sumber yaitu akal pikiran, berhubungan dengan fungsi sebagai penilaian terhadap perbuatan yang dilakukaukan oleh manusia. ${ }^{2}$ Perbuatan-perbuatan ini yang dapat mengakibatkan problematika atau kemajuan masyarakat, khususnya peserta didik.

Realitas dan fakta telah terjadi pergeseran nilai etika dan kepribadian dalam masyarakat memunculkan berbagai problematika yang mengancam harmonisasi dalam interaksi sosial, baik di lingkungan keluarga, sekolah dan masyarakat. Standar etika dan kepribadian yang digariskan oleh nenek moyang

\footnotetext{
${ }^{1}$ Hamzah Ya'qub, Etika Islam (Bandung: Rineka Cipta, 1983), 12. Lihat pula Burhanuddin Salam, Etika Individual Pola Dasar Filsafat Moral (Jakarta: Rineka Cipta, 2000), 30.

2 Abudin Nata, Akhlak Tasawuf (Jakarta: RajaGrafindo Persada, 1997), 88.

Jurnal Pendidikan Agama Islam (Journal of Islamic Education Studies)

Volume 5 Nomor 2 (2017)

ISSN(p) 2089-1946\& ISSN(e) 2527-4511

Hal. 310 - 338
} 
dan berjalan turun temurun sudah tidak lagi menjadi pilihan bagi generasi sekarang, khususnya peserta didik di lembaga pendidikan Islam.

Hal yang penting dilakukan adalah merumuskan standar dan konsep etika dan kepribadian yang bersumber dari al-Qur'an dengan cara mengkaji secara mendalam content ayat-ayat yang berkaitan dengan etika dan kepribadian. ${ }^{3}$ Sedangkan etika dan kepribadian terkait erat dengan psikologi manusia atau jiwa manusia, karena psikologi merupakan ilmu yang mempelajari teentang jiwa, sedangkan jiwa adalah daya hidup rohaniyah yang bersifat abstrak, menjadi penggerak dan pengatur perbuatan-perbuatan pribadi (personal behavior) manusia. Perbuatan pribadi adalah perbutan yang bersumber dari proses hasil belajar, proses hasil belajar inilah yang dapat meningkatkan kepribadian (personality) dengan jalan mendapatkan nilai-nilai kebudayaan dan nilai-nilai keislaman. ${ }^{4}$ Rumusan psikologi dan aspek kejiwaan manusia harus dicari dari al-

${ }^{3}$ Langkah-langkah metode analisis isi (content analysis) dalam penelitian ini dimulai dengan: a) Unitizing, yaitu menyatukan, mengelompokkan atau mengidentifikasi data-data mana yang dapat dipilih sebagai sumber penelitian, yaitu ayat-ayat al-Qur'an yang mempunyai korelasi dengan konsep etika dan kepribadian untuk dikelompokkan, diklasifikasi menjadi temuan penelitian. b) Sampling, dalam penelitianini adalah pengambilan bagian dari informasi dan sumber data yang akan diteliti. c) Recording, yaitu proses pengumpulan data dengan cara mencatat, merekam data, memberi kode data supaya data dapat lebih fokus dan lebih mudah dipakai dalam mendukung penelitian. d) Reducing, yaitu merangkum, memilih data-data atau informasi yang pokok, fokus terhadap hal-hal yang penting. Reducing juga berusaha mencari tema dan pola data dan informasi agar data dapat memberi gambaran yang jelas dan mempermudah untuk melakukan pengumpulan data selanjutnya. e) Inferring, yaitu menarik kesimpulan dari sumber-sumber yang telah direduksi. f) Analyzing, yaitu menilai data yang telah direduksi sesuai dengan kontek dan mendiskripsikan secara eksplisit. g) Narrating, bermakna memaparkan dan menyajikan data-data berupa ayat-ayat al-Qur'an yang terfkait dengan yang telah dianalisis dan dinilai untuk kemudian juga dinarasikan sebagai sebuah kesimpulan. Lihat Klaas Krippendorff Content Analysis; An Introduction to Its Theory and Methodology, Terj. Farid Wajidi (Jakarta: Raja Grafindo, 1993), 4-9.

4 Nilai-nilai keislaman adalah konsepsi- konsepsi tentang kebaikan dan keburukan sesuai dengan dasar hukum yang bersumber dari al-Qur'an dan al-Hadis. Nilai-nilai keislaman tersebut ada ada dua macam, yaitu nilai ilahiyyah, yaitu nilai yang langsung turun dari Allah (nilai yang bersumber dari al-Qur'an) serta nilai insaniyyah, yaitu nilai-nilai yang tumbuh dan berkembang dari peradaban manusia. Nilai-nilai ilahiyyah ini tidak mengalami perubahan, fundamental dan bersifat statis, mengandung kemutlakan bagi kehidupan manusia selaku pribadi maupun anggota masyarakat, tidak punya kecenderungan berubah sesuai denngan tuntutan perubahan sosial dan tuntutan Sedangkan nilai-nilai insaniyyah ini dapat mengalami perubahan, namun secara intrinsiknya tetap tak berubah, karena jika nilai intrinsiknya berubah maka sumber nilai yang berupa wahyu juga dapat mengalami kerusakan. Pada aspek nilai ilahiyyah ini, tugas pendidikan adalah menginterpertasikan nilai-nilai itu pada kehidupan manusia. Nilai-nilai Ilahiyyah itu di dalamnya ada potensi fitrah yang berupa alIslam dan al-Hanafiah yang harus diinterpertasikan melalui pendidikan. Tugas pendidikan di sini adalah bagaimana nilai ilahiyyah yang berupa potensi fitrah tersebut diinterpertasikan pada peserta didik supaya dapat hidup damai. Adapun nilai insaniyyah yang tumbuh 
Qur'an kemudian didesain bagimana membangun etika dan kepribadian peserta didik secara tepat di lembaga pendidikan Islam. ${ }^{5}$ Berdasarkan deskripsi tersebut, penulis tertarik melalukan penelitian pustaka ini. Maka penjelasan lebih dalam tentang etika dan keperibadian (ethic and personality) dalam perspektif psikologi Qur'ani, akan penulis uraikan pada bagian selanjutnya.

\section{B. Konsep Etika dan Kepribadian (Ethic and Personality)}

Ethic atau etika dimaknai dengan ilmu pengetahuan tentang asas-asas akhlak (moral). 6 Konsep etika awal munculnya dari bahasa bahasa Yunani "ethos" yang berarti tempat tinggal, padang rumput, kandang, kebiasaan/adat, akhlak,watak, perasaan, sikap, cara berpikir. Secara general, etika terkait erat dengan adat kebiasaan atau ilmu yang terkait dengan itu. Makna lain dari etika yaitu nilai-nilai moral yang berkembang di masyarakat dan diikuti sebagai landasan bertindak dan berpikir. Etika juga bermakna sebagai watak kesusilaan

berkembang melalui peradaban manusia itu bersifat dinamis dan berlakunya juga berubah. Perubahan tersebut dapat diklasifikasikan menjadi tiga bagaian: a) Perubahan secara konservatif. Perubahan ini mengacu pada nilai lama yang sudah mapan walaupun itu tampak irasional. b) Perubahan secara radikal revolusioner. perubahan ini mengarah pada pencabutan nilai-nilai sampai akarnya karena nilai lama tersebut sudah mengalami stagnasi. c) Perubahan secara reformatif. Perubahan ini mengarah pada perpaduan nilai konservatif dan radikal revolusioner, yakni perubahan dan pergeseran nilai-nilai dengan perlahan-lahan sesuai dengan tuntunan Nabi Muhammad saw. Nilai-nilai insaniyyah tersebut di dalamnya terkandung aspek kognisi dan persepsi yang harus dikembangkan oleh pendidikan kearah yang lebih baik. Perubahan tersebut menurut penulis harus bersifat reformatif sesuai dengan tuntunan Nabi Muhammad saw. Dari sisi lain, nilai keislaman yang harus dibentuk dan dikembangkan dalam pendidikan Islam di antaranya adalah kesalehan, keimanan, ibadah dan akhlak. M. Arifin, Filsafat Pendidikan Islam (Jakarta: Bina Aksara, 1987), 121. Lihat pula Noeng Muhadjir, Ilmu Pendidikan dan Perubahan Sosial (Yogyakarta: Rakesarasin, 1987), 144. Bandingkan dengan Abu Ahmadi, Psikologi Belajar (Jakarta: Rineka Cipta, 2013), 1.

5 Menemukan konsep psikologi qur'ani dalam hal ini dengan menggunakan cara: a) Menghimpun ayat-ayat yang berkaitan dengan psikologi, materi tentang jiwa dalam al-Qur'an dengan memasukkan kata kunci pada software komputer. b) Mengalisis korelasi (munāsabat) ayat-ayat yang sesuai dengan materi psikologi. Munāsabat dibagi menjadi 2 (dua) yaitu : Zāhir ar-Irtibāt (persesuaian yang nyata) dan khäfiy al-Irțibāt (persambungan yang tidak jelas). c) Mengkaji asbāb al nuzūl-nya. Sebab-sebab turunya ayat ini diperlukan dalam rangka mengetahui hikmah turunnya ayat. d) Melengkapi dengan hadis-hadis yang relevan serta pendapat para ulama sebagai pendukung. e) Melakukan interpretasi ayat serta merumuskannya. f) Menyimpulkan hasil interpretasi yang menjadi hasil dari penelitian. Abd al Hayy al-Farmawi, Al-Bidayah Fi Al-Tafsir al-Maudhu'i (Mesir: Maktabah al-Jumhuriyah, 1977), 23. Lihat pula Ridlwan Nasir, Memahami al-Qur'ān Perspektif Baru Tafsìr Muqarrin (Surabaya: Indra Media, 2003), 14-17. Lihat pula Imam Muchlas, Himpunan Orasi Ilmiah Pengukuhan Guru Besar IAIN Sunan Ampel (Surabaya: IAIN Sunan Ampel Press, 2004), 280284.

6 W.J.S. Poerwadarminta, Kamus Umum Bahasa Indonesia (Jakarta: Balai Pustaka, 1993), 278.

Jurnal Pendidikan Agama Islam (Journal of Islamic Education Studies)

Volume 5 Nomor 2 (2017)

ISSN(p) 2089-1946\& ISSN(e) 2527-4511

Hal. 312 - 338 
atau adat yang dalam hal ini berbeda dengan akhlak dan moral. ${ }^{7}$ Jadi dalam hal ini etika terkait dengan ilmu pengetahuan, perilaku baik dan buruk, norma-norma yang disepakati oleh manusia. ${ }^{8}$ Al-Attas menyamakan etika dengan Adab, yaitu kebaikan secara menyeluruh yang meliputi kehidupan material dan spiritual dan berusaha menanamkan kualitas hidup kebaikan dalam perilakunya. ${ }^{9}$

Islam menyandingkan makna ethic dengan akhlāq berasal dari bahasa Arab yang berarti al-sajiyah (perangai), al-tabi'ah (kelakuan, tabi'at, watak dasar), al-'adàt (kebiasaan, kelaziman), al-maru'ah (peradaban yang baik), dan al-din (agama).10 Akhlak dapat diartikan dengan tabi'at, perangai, kebiasaan. ${ }^{11}$ Akhlak juga bermakna suatu sifat atau keadaan yang tertanam dalam jiwa yang berakibat memunculkan perbuatan-perbuatan konstan, spontanitas tanpa memerlukan pemikiran dan pertimbangan. ${ }^{12}$ Akhlak adalah sifat jiwa yang tertanam dalam jiwa, yang dengannya lahirlah macam-macam perbuatan, baik atau buruk, tanpa membutuhkan pemikiran dan pertimbangan. ${ }^{13}$

Pendapat para Ilmuwan tentang akhlak dapat disimpulkan sebagai berikut; a) Akhlak merupakan perbuatan yang ada dalam jiwa seseorang dan tertanam secara kuat sehingga telah menjadi kepribadiannya. b) Akhlak merupakan perbuatan yang dilakukan dengan tanpa berpikir terlebih dahulu (spontanitas). c) Akhlak adalah perbuatan yang bersumber dari dalam diri

${ }^{7}$ Abuddin Nata, Akhlaq Tasawwuf (Jakarta: Raja Grafindo Persada, 2002), 87.

8 Term etika, moral, akhlak dan susila memiliki beberapa perbedaan dan persamaan. Akhlak menurut Islam bermakna luas, yaitu berhubungan dengan manusia dan mahluk hidup serta alam semesta. Ciri-ciri perbuatan yang dianggap akhlak di antaranya; Prilkuu sudah tertanam dalam jiwa seseorang, dan menjadi kepribadian, perilaku dilakukan dengan tanpa pemikiran, perilaku dilakukan secara sadar dari hati dan bukan paksaan dari luar dirinya, perilaku dilakukan dengan ikhlas karena Allah, bukan karena yang lain. Baca Abudin Nata, Akhlak Tasawuf(Jakarta: Raja Grafindo Persada, 1997), 6. Moral dalam Encyclopedia of Islam berasal dari bahasa Arab "Adab" yang berarti adat istiadat, kebiasaan, dan etika atau sopan santun yang digunakan manusia dalam berinteraksi dengan sesamanya. Dalam bahasa Latin disebut "urbanitas" yang bermakna kehalusan dan kebaikan dan tata krama yang merupakan antitesa dari perbuatan kasar atau kebiasaan-kebiasaan buruk. Lihat Muhammad Abdurrahman, Baru: Rekonstruksi atas Moralitas Pendidikan (Yogyakarta: Primasophie, 2003), 74. Adapun "susila" berasal dari bahasa Sansekerta, yaitu "su" berarti bagus, baik dan "sila" berarti prinsip, dasar, aturan hidup, nilai dan norma. Garis besarnya, "susila" merupakan pedoman bagi manusia untuk hidup dengan baik bersumber pada nilai-nilai yang ada dimasyarakat dan berpedoman pada sesuatu yang dipandang baik. Said, Etika Masyarakat Indonesia (Jakarta: Pradnya Paramita, 1976), 22.

${ }^{9}$ Naquib al-Attas, Islam dan Secularism, Terj.Karsidjo (Bandung: Pustaka, 1981), 222.

${ }^{10}$ L. Ma'luf, Kamus al-Munjīd (Beirut: Dār al-Mashriq, 1986), 193.

${ }^{11}$ M. Quraish Shihab, Wawasan al-Qur'an: Tafsir Maudhu'i atas Pelbagai PersoalanUmat, (Bandung: Mizan: 1998), Cet. VIII, 253.

${ }^{12}$ Al-Ghazali, Ihya 'Ulūm al-Dīn, Juz III (Beirut: Dār al-Kutūb al-'Ilmiyah, t.t.), 57.

${ }^{13}$ Ibnu Miskawaih, Tahdzīb al-Akhlāq, Terj. Helmi Hidayat (Bandung: Mizan, 1994), Cet. 2, 56. 
manusia tanpa ada pengaruh dari luar. d) Akhlak adalah perbuatan yang dilakukan dengan perintah langsung dari hati dan jiwa sehingga terhindar dari ketidakjujuran.

Sedangkan personality (kepribadian) adalah istilah yang digunakan pada perilaku sosial tertentu yang diterima oleh individu dari kelompok atau masyarakatnya. ${ }^{14}$ Ahli psikologi menggunakan kata personality untuk menunjukkan sesuatu yang nyata dan dapat dipercaya terhadap individun dan menggambarfkan bagaimana perilaku dan kehidupannya di masyarakat. Personality merupakan tingkah laku yang saling berhubungan yang tersusun berdasarkana nilai-nilai yang bersumber dari kesepakan masyarakat, wahyu ilahi atau yang lainnya yang berpengaruh pada tindakan dan perbuatan dan membedakan antara manusia satu dengan yang lainnya. ${ }^{15}$

Personality (kepribadian) pada diri manusia akan mengalami perkembangan dan perubahan, mulai dari anak-anak, remaja sampai dewasa niscaya mengalami perkembangan yang signifikan dengan pola-pola tertentu. ${ }^{16}$ Hal ini berarti, bahwa personality itu dinamis, tidak statis selalu mengalami perubahan karena ada perubahan tertentu, seperti pengaruh pendidikan, pengaruh lingkungan, pengaruh masyarakat. Oleh karean itu kepribadian manusia satu dengan yang lain mengalami perbedaan.

\section{Psikologi Qur'ani sebagai Sebuah Perspektif}

\footnotetext{
${ }^{14}$ Hadi Subrata, Mengembangkan Kepribadian Anak Balita (Jakarta: Gunung Muria, 1997), 2.

15 Ngalim Purwanto, Psikologi Pendidikan (Bandung: Rosdakarya, 1996), 152.

16 Daniel Goleman menyatakan, bahwa personality tidak berdiri sendiri, melainkan terkai dengan hal-hal yang lain seperti aspek Emotional Quetion-nya. Personality dan Emotional Quetion dapat dibangaun melalui hal-hal sebagai berikut; a) Kesadaran Diri; mengetahui apa yang kita rasakan suatu saat dan menggunakannya untuk mengambil keputusan diri sendiri, memiliki tolak ukur yang realistis atas kemampuan diri dan kepercayaan diri yang kuat. b) Pengaturan Diri; Mampu menangani dan mengarahkan emosi kita sedemikian rupa sehingga berdampak positif terhadap pelaksanaan tugas; peka terhadap kata hati dan sanggup menunda kenikmatan sebelum tercapainya suatu sasaran; mampu pulih kembali dari tekanan emosi. c) Motivasi ; Menggunakan hasrat kita yang paling dalam untuk menggerakkan dan menuntun kita menuju sasaran, membantu kita mengambil inisiatif dan bertindak efektif, bertahan dalam menghadapi kegagalan dan frustasi. d) Empati; Merasakan yang dirasakan orang lain, mampu memahami perspektif mereka, menumbuhkan hubungan saling percaya dan menyelaraskan diri dengan bermacam-macam orang. e) Keterampilan Sosial; Mampu menangani emosi dengan baik ketika berhubungan dengan orang lain dan cermat membaca situasi dan jaringan social; berinteraksi dengan baik dan lancer; menggunakan keterampilan-keterampilan ini untuk mempengaruhi dan memimpin, bermusyawarah dan menyelesaikan perselisihan, mampu bekerja sama dan bekerja dalam tim. Daniel Goleman, "Working with Emotional Integence”, dalam Agus Nggermanto, Quantum Quotient (Bandung: Nuansa, 2001), 166.
}

Jurnal Pendidikan Agama Islam (Journal of Islamic Education Studies)

Volume 5 Nomor 2 (2017)

ISSN(p) 2089-1946\& ISSN(e) 2527-4511

Hal. 314 - 338 
Psikologi berasal dari bahasa Yunani psyce (jiwa) dan logos (ilmu pengetahuan). Psikologi secara terminologi adalah ilmu pengetahuan yang mempelajari tentang jiwa manusia, mengenai macam-macam gejalanya, prosesnya maupun latarbelakangnya. ${ }^{17}$ Obyek psikologi pada dasarnya adalah manusia dengan segala potensi dan kelebihan yang diberikan oleh Allah yang harus dikembangkan melalui pendidikan. ${ }^{18}$

17 Ahmadi, Psikologi Belajar, 1-2.

${ }^{18}$ Manusia perspektif psikologi qur'ani dipahami dari beberapa kata kunci dalam al-Qur'an: a) Kata insân yang dalam bentuk jamaknya adalah al-Nâs bermakna melihat, mengetahui minta izin. (QS. Thâha: 10, al-Nisâ': 6), bermakna minta izin (QS. al-Nûr: 27). Jika insân diambil dari kata al-Uns atau anisa dapat bermakna jinak, lembut, mudah dididik. atau bermakna jinak, harmonis, tampak. Makna ini lebih tepat dibanding dengan kata insân yang diambil dari kata nasiya (lupa) atau nâsa-yanûsu yang berarti berguncang. Kata anasa disebut dalam al-Qur'an sebanyak 25 kali. sedangkan kata insân disebut dalam al-Qur'an sebanyak 66 kali. Kata unâs disebut dalam al-Qur'an sebanyak 5 kali. Jadi lafad anâsa dengan segala perubahan bentuknya disebut 90 kali dalam al-Qur'an. Interpretasi kata-kata tersebut dijelaskan sebagai berikut: Pertama: kata insân bermakna melihat, mengetahui, minta Izin yang mengandung petujuk adanya kaitan substansial antara kemampuan manusia dan nalarnya, artinya dengan nalar tersebut manusia akan dapat mengambil pelajaran terhadap apa yang dilihatnya, mengetahui yang benar dan yang salah, terdorong untuk minta izin dalam memakai sesuatu yang bukan miliknya. Secara kontekstual, manusia lebih menyadari kebermaknaan hidupnya jika ia mampu mengaktualkan dirinya melalui aktifitas etik dan moral, intelektual dan kultural. Kedua: Kata insân jika dilihat dari asalnya al-uns atau anisa dapat bermakna lembut, jinak, mudah di didik, makna ini dapat diinterpretasikan, bahwa manusia pada dasarnya adalah lembut,jinak, dapat menyesuaikan diri dengan realitas hidup dan lingkungan yang ada. Manusia punya kemampuan yang tinggi untuk beradaptasi dengan lingkungannya, karena jinak manusia tidak termasuk mahluk yang liar, dalam arti dapat di didik dengan mudah. manusia dalam kontek ini dapat diberi pelajaran dan dididik, derajat manusia dalam kontek ini ditentukan oleh ibadah dan perbuatannya. (QS. al-Thîn: 4-8). Lihat M. Quraish Sihab, Wawasan al-Qur'an (Bandung: Mizan, 1997), 280. Lihat pula Fuad Abdul Baqi, Mu'jam alMufahras li alfâd al-Qur'an (Beirut: Dār al-Fikr, 1992), 119-120. b) Kata Basyar, dengan segala bentuk perubahannya disebut 122 kali dalam al-Qur'an.. Dalam bentuk tunggal al-Qur'an menggunakan kata ini sebanyak 36 kali, kata ini terambil dari akar kata yang pada mulanya berarti "penampakan sesuatu yang baik dan indah" . Dari akar kata yang sama lahir kata alBasyarah yang bermakna kulit".Manusia yang dinamai basyar karena kulitnya tampak jelas dan beda dengan kulit binatang. Pemakaian kata basyar di beberapa tempat dalam al- Qur'an seluruhnya merupakan pengertian bahwa yang dimaksud dengan kata tersebut adalah untuk anak Adam secara dhahir (lahiriah) serta persamaannya dengan manusia seluruhnya. Ali Syariati menyatakan manusia dalam pengertian basyar adalah makhluq yang sekedar ada (state of being) secara fisiologis, berdasarkan kata tersebut walaupun manusia mengalami proses pertumbuhan dan perkembangan. Tetapi itu hanya merupakan rangkaian evolusi biologis mekanistik. Ini artinya kata basyar dimaksudkan untuk menggambarkan manusia secara fisik, dalam pengertian ini, manusia dipahami dari apa yang nampak secara lahiriah dalam seluruh proses kehidupan (QS. al-Rum: 20). Basyar yang disebut dalam al-Qur'an itu dimaksudkan untuk kontek manusia dalam bentuk lahiriah. (QS. al-Mudatsir: 27), (QS. alAnbiya': 344). Pengertian bashärtidak lain adalah manusia dalam kehidupan sehari-hari yang berkaitan dengan kehidupan sehari-hari yang dipengaruhi oleh dorongan kodrat alamiah, 
Teori psikologi yang dikembangkan Benyamin S.Bloom dkk menyatakan, bahwa dimensi psikologi manusia terbagi atas tiga ranah; kognitif, afektif dan psikomotorik. Kognitif terdiri dari: 1) Knowledge (Pengetahuan); bagaimana peserta didik mampu mengetahui hal yang terkait dengan materi pelajaran. Seperti mengetahui istilah, fakta, aturan ataupun metode. 2) Comperhension (Pemahaman); Bagaimana peserta didik dapat menjelaskan, memahami atau menentukan metode, konsep, kaidah ataupun isi pokok dari materi pelajaran. 3) Application (Penerapan); Bagaimana peserta didik dapat memecahkan masalah, membuat atau menggunakan konsep, kaidah, prinsip yang telah diajarkan. 4) Analysis (Analisa): Bagaimana peserta didik dapat mengenali kesalahan, membedakan, menganalisa fakta, menganalisa struktur dasar dan hubungan antara komponen satu dengan yang lain. 5) Synthesis (Sintesa); Bagaimana peserta didik dapat menghasilkan karangan, kerangka teoritis dari materi pelajaran. Atau dapat menyusun rencana, skema, program kerja. 6) Evaluation (Evaluasi); Bagaimana peserta didik dapat menilai berdasarkan norma tentang hasil karya, mutu karangan, mutu pekerjaan, mutu ceramah, program penataran. Atau dapat mempertimbangkan baik-buruk, untung rugi atau pro-kontra dari materi yang telah disampaikan.

Afektif terdiri dari: 1) Receiving (Penerimaan); Bagaimana peserta didik dapat menunjukkan kesadaran, kemauan dan perhatian terhadap sesuatu yang telah diterima. Atau dapat mengakui berbagai perbedaan dan kepentingan. 2) Responding (Partisipasi); Bagaimana peserta didik dapat mematuhi tuntutan, perintah, aturan yang ada. Atau dapat ikut secara aktif dalam diskusi, kelompok, belajar di Laboratorium. 3) Valuing (Penilaian); Bagaimana peserta didik dapat menerima, menyukai, menyepakati dan menghargai karya, ilmu dan pendapat. Atau dapat bersikap secara positif atau mengakui kebenaran lain selain apa yang diyakininya. 4) Organization (Organisasi; Bagaimana peserta didik dapat membentuk sistem dan mengintegrasikan nilai saekaligus bertanggung jawab terhadap peristiwa yang terjadi. 5) Characterization (Pembentukan pola hidup); Bagaimana peserta didik dapat menunjukkan kepercayaan diri, disiplin dan kesadaran pribadi atau dapat mempertimbangkan dan melibatkan diri pada peristiwa tertentu.

Psikomotor terdiri dari: 1) Perception (Persepsi; Bagaimana peserta didik dapat peka terhadap rangsangan, mengidentifikasikan persoalan yang terjadi.

seperti makan minum dan lain- lain. c) Kata "Banî âdam atau Durriyat âdam".Kata ini dipakai al-Qur'an secara umum untuk menunjuk pada manusia secara umum, baik kapasitasnya sebagai basyar maupun insân. Kata Banî âdam atau Durriyat âdam tidak banyak dipakai oleh al-Qur'an dibanding dengan kata al-Nâs yang menunjukkan aktifitas suatu kelompok. (QS. alMa'idah: 27). Baca Ali Syariati, Man And Islam (Houston: Filinic Press, 1974), 4. Bandingkan dengan Fuad Abdul Baqi, Mu'jam al-Mufahras li alfâd al-Qur'an (Beirut: Dār al-Fikr, 1992), 119.

Jurnal Pendidikan Agama Islam (Journal of Islamic Education Studies)

Volume 5 Nomor 2 (2017)

ISSN(p) 2089-1946\& ISSN(e) 2527-4511

Hal. 316 - 338 
Atau peserta didik dapat membedakan hal-hal yang terbaik dan tidak dalam materi pengajaran. 2) Set (Kesiapan); Bagaimana peserta didik dapat berkonsentrasi, menyiapkan diri baik secara fisik atau mental untuk menerima dan mencerna setiap materi yang diberikan. 3) Guided Response (Gerakan terbimbing); Bagaimana peserta didik dapat meniru dan mencontoh apa yang telah dipelajari dikelas. Atau peserta didik dapat mempraktekkan materi pelajaran yang telah disampaikan. 4) Mechanism (Gerakan mekanis/ terbiasa); Bagaimana peserta didik dapat berketerampilan dan mampu mmegang pola atas materi yang dia terima. Atau peserta mampu mendemonstrasikan, mengoprasikan sesuatu hal sesuai dengan materi yang diterima. 5) Complex Overt Response (Gerakan Respon); Bagaimana peserta didik dapat berketarampilan secara lancar, luwes, gesit dan lincah di setiap tindakannya. 6) Adaptation (Adaptasi); Bagaimana peserta didik dapat beradaptasi terhadap hal-hal yang baru. ia terima, terutama berkait dengan materi pelajaran. Atau peserta didik dapat membuat variasi atas segala sesuatu. 7) Organitation (Kreatifitas); Bagaimana peserta didik dapat menciptakan sesuatu yang baru dan berinisiatif untuk bertkreasi dan berkarya atau peserta didik mampu merancang dan menyusun dengan pola yang baru atas sesuatu yang mereka terima. ${ }^{19}$

Di sisi lain, Al-Qur'an (Psikologi Qur'ani) memahami manusia adalah mahluk yang paling sempurna yang diciptakan oleh Allah yang sejak lahir manusia sudah diberi komponen psikologis yang berupa daya dan kemampuan sebagai bekal hidup di dunia dan akhirat. (QS. Al-Rum: 30). Komponen psikologis itu di antaranya:

Pertama, kemampuan dasar untuk beribadah dan beragama. Kemampuan ini ada pada manusia sebagai pernyataan pengabdian pada Tuhannya hal ini mengandung unsur kemampuan dasar beragama Islam (al-Dîn al-Qayyîm) maupun kemampuan dasar beragama secara umum, artinya beragama tersebut sebagai wujud pengabdian terhadap Dzat yang menciptakannya atau sesuatu yang dianggap oleh manusia sebagai sesuatu yang agung dan mulia. Kemampuan dasar untuk beragama, beribadahIbadah dalam hal ini adalah pengagungan seorang hamba kepada Dzat yang menciptakannya. Atau pernyataan akan penerimaan hamba itu akan tuntutan moralnya. Melalui ibadah seorang hamba mengharap khaliqnya akan menolong, membimbing menuju jalan yang benar. Hal ini merupakan sesuatu yang secara inhern yang terdapat pada kecendrungan alami

19 Benyamin S. Bloom, Taksonomy of Educational Objectives; The Clasification of Educational Goals, Handbook 1 Cognitive Domain (London: Longman Group Ltd, 1979), 220-225. Lihat pula Orin Anderson and David R.Krathwohl, A Taxonomi for Learning; Teaching and Assassing, A Revision of Bloom's Taxonomi of Educational Objectives (New York: Longman Press, 2001), 29. 
manusia dan alam kejadian asalnya sendiri. Karena itu perpindahan dari bentuk tindakan ubudiyah kebentuk yang lain dapat dilihat sebagai tindakan substantif belaka. Oleh karena itu dalam kenyataan hidup manusia hampir tidak ada individu yang bebas satu sama sekali dari bentuk ekspresi pengagungan yang punya nilai ubudiyah (devotional). Seperti halnya jika seseorang tidak melakukan suatu bentuk tindakan ubudiyah tertentu yang standar (seperti salat dalam Islam), maka ia tentu melakukan bentuk tindakan ubudiyah yang lain. Seperti kaum komunis yang punya kecendrungan mengagungkan pemimpinnya. Hal itu mengindikasikan bahwa fitrah manusia itu memang dari asalnya punya potensi untuk beribadah dalam arti punya potensi untuk mengagungkan sesuatu yang dianggap paling tinggi atau paling kuat yang dapat membimbing didrinya kepada jalan yang benar atau juga yang dapat melindungi dirinya.

Kedua, kemampuan dasar yang berupa dorongan ingin tahu terhadap kebenaran yang dibawa sejak lahirnya yang itu diberikan pada setiap individu manusia. Tetapi masalahnya potensi yang sudah ada pada manusia ini dapat digunakan juga tidak digunakan, ini tergantung pada kebiasaan-kebiasaan yang dilakukan dan dapat dibentuk melalui pendidikan. Dorongan ingin tahu manusia terhadap kebenaran ini bila dikembangkan melalui pendidikan maupun pengajaran niscaya akan dapat berkembang menjadi : (a) Dorongan untuk mencari Tuhannya, (b) Dorongan untuk selalu menerima kebaikan dan ketentraman, (c) Dorongan untuk berfikir mencari hakekat kebenaran.

Ketiga, kemampuan dasar yang berupa daya-daya atau kekuatan yang memungkinkan manusia menjadi mulia, baik dimata manusia maupun disisi Allah. Dengan catatan manusia itu dapat mengaktualisasikan daya pikir (quwwah al$A q l$ ), daya ofensif (quwwah al-Sahwah), daya devensif (quwwah al-Ghadab). Quwwah al-Aql adalah suatu potensi yang berfungsi untuk mengetahui Allah (ma'rifatullah) dan mengesakannya. Potensi inilah yang memungkinkan manusia untuk beriman kepada Allah. Bila anak dilahirkan kemudian ia berusaha untuk mengingkari Allah maka ia ini diakibatkan tidak berfungsinya potensi ini yang mengakibatkan kekafiran dan kemusyrikan. (QS.al-An'âm:151, al-Mulk:10, alAnkabût:43, al-Baqarah:164).

Manusia lahir telah dibekali kemampuan dasar yang berupa jasmani dan rohani, quwwah al-Aql ini ada secara inhern ada rohani manusia. Dengan quwwah al-Aql ini manusia akan dapat membedakan perbuatan yang membawa kepada kebaikan atau keburukan. Di dalam quwwah al-Aql ada dua unsur yang disebut alNadzar dan al-Irädah. Al-Nadzar meliputi daya-daya kognisi, persepsi dan komperhensi. Al-Iradah meliputi daya-daya emosi dan kemampuan untuk menilai. Oleh karena itu manusia dilahirkan cenderung melakukan kebaikan dan meninggalkan keburukan karena itulah fitrahnya. Quwwah al-Sahwah 
(concupicible power) ialah daya yang berpotensi untuk menginduksi obyek-obyek yang menyenangkan dan bermanfaat. Pengingkaran terhadap hal ini akan menimbulkan perbuatan yang terlarang. Quwwah al-Ghadab (the repulsive faculty) yaitu yang berpotensi untuk menghindarkan diri dari hal yang membahayakan. Pengingkaran terhadap potensi ini akan mengakibatkan kejahatan. Oleh karena itu quwwah al-Ghadab ini harus dikendalikan. ${ }^{20}$

Adapun secara spesifik, Islam mempunyai konsep yang tertulis dalam AlQur'an terkait dengan psikologi dan ilmu psikologi (jiwa/ilmu jiwa). Jiwa adalah daya hidup rohaniyah yang bersifat abstrak, mampu menjadi motor penggerak, pengatur perilaku, perbuatan hidup pribadi seseorang (personal behavior). Perbuatan pribadi ialah perbuatan yang dihasilkan dari proses belajar di manapun berada. Proses belajar adalah proses untuk meningkatkan kepribadian (personality) dengan jalan mendapatkan nilai-nilai baru dalam kehidupan, mendapatkan norma-norma dari pesan agama, memperoleh nilai baik dari kebudayaan manusia. Hal ini akan dijelaskan melaui kata kunci al-Nafs, al-Lubb, al-fu'ad, al-Hilm, al-Hijr, al-Nuhyah, al-Syu'ur, al-Ruh, al-Aql, al-Qalb.

1. Al-Nafs

Kata Nafs diartikan sebagai satu komponen dasar manusia yang berwujud immateri yang secara umum dipakai dalam kontek yang berkaitan dengan manusia, baik yang berpotensi baik dan buruk. Nafs dalam diri manusia berfungsi mengarahkan manusia untuk berperilaku dalam kehidupannya, manusia dapat emosional dapat juga lemah lembut karena Nafs. Nafs pada hakekatnya cenderung melakukan pekerjaan yang baik daripada pekerjaan yang buruk. ${ }^{21}$

Teks ayat di atas dapat dipahami, bahwa dengan Nafs memungkinkan manusia dapat menangkap aspek kebaikan dan keburukan, tetapi antara aspek

${ }^{20}$ QS. al-Isrâ' : 70, al-A'râf: 179, al-Fajr: 27-30, al-Furqân: 68.

${ }^{21}$ Al-Qur'an memakai kata nafs dibeberapa ayat, diantaranya QS. Al-Samms: 7-8: “ dan Jiwa serta penyempurnaannya, maka Allah mengilhamkan kepada Nafs (Jiwa) itu jalan kefasikan dan ketakwaan". QS. Al-Baqarah: 286: “Allah tidak akan membebani seseorang (Nafs) melainkan sesuai dengan kesanggupannya. Ia mendaoat pahala (dari kebajikan) yang diusahakannya dan ia mendapat siksa (dari kejahatan) yang dikerjakannya" . QS. Al-Fajr; $27-$ 30: " Hai jiwa (nafs) yang tenang, kembalilah pada Tuhanmu dengan hati yang puas lagi diridhoi-Nya, maka masuklah kedalam jama'ah hamba-hamba-Ku, dan masuklah kedalam Surgaku”. QS.al-Ra'd:11:“ Sesungguhnya Allah tidak akan merubah keadaan suatu kaum sehingga mereka merubah keadaan yang ada pada diri (nafs) mereka sendiri”. Ayat lain juga dijelaskan bahwa nafs juga merupakan wadah yang menampung gagasan dan kemauan. Kemauan di sini sebagai unsur yang menginginkan perubahan dalam dirinya, yaitu QS. alRa'd:11: " Sesungguhnya Allah tidak akan merubah keadaan suatu kaum sehingga mereka merubah keadaan yang ada pada diri (nafs) mereka sendiri”. 
baik dan buruk tersebut tidaklah sama. Hal ini berarti, bahwa unsur positif itu lebih dominan dibanding unsur negatifnya. Quraish Shihab memaknai Nafs dengan "usaha baik" sehingga memperoleh ganjaran yang baik. Nafs merupakan "wadah" yang menampung gagasan dan kemauan. Kemauan di sini sebagai unsur yang menginginkan perubahan dalam dirinya.

Nafs mempunyai beberapa unsur yang melekat meliputi; potensi kebaikan, keburukan, kemauan, di sini tugas pendidikan harus mengarahkan pada pengembangan Nafs (jiwa) ini pada aspek kebaikan dan menghilangkan aspek keburukannya, menumbuhkan kemauan untuk berbuat baik, mengubah hidupnya sesuai yang dikehendaki Allah.

2. $A l-L u b b$

Kata Lubb bentuk jama'nya adalah albâb disebutkan dalam al-Qur'an dalam bentuk jama' sebanyak 16 kali dan digandengkan dengan kata "Ulu" atau "Uli" yang artinya adalah cerdik. Abdurrahman Saleh Abdullah mengartikan $L u b b$ dengan esensi dari segala sesuatu. Sedangkan al-Qurtubi "Ulu albâb" mengartikan sebagai "orang yang merenungi bukti-bukti rasional dengan penuh kesadaran". At-Ṭabari, menyatakan bahwa Lubb adalah kemampuan membedakan antara yang baik dan yang buruk. ${ }^{22}$

Adapun al-Qurtubi Ulu albâb sebagai orang yang merenungi buktibukti rasional dengan penuh kesadaran. ${ }^{23}$ Sedangkan At-T Tabari, menyatakan bahwa $l u b b$ adalah kemampuan membedakan antara yang baik dan yang buruk. ${ }^{24}$ Konteknya, bahwa manusia dengan Lubb-nya mempunyai kemampuan untuk membedakan baik buruk dengan bukti rasional. Dengan bukti rasional ini, manusia diharapkan bisa mengontrol prilaku kehidupan sehari-hari dengan baik.

3. Al-Fu'ad

Kata Fu'ad disebut al-Qur'an sebanyak 16 kali, tujuh kali di antaranya dipakai berhubungan dengan penglihatan dan pendengaran, selebihnya dihubungkan dengan pendengaran saja atau penglihatan serta ada yang menunjukkan pada sifat emosional dan psikologi, yaitu pada QS. al-Qasas: 10 yang mengandung " keteguhan hati": " Sesungguhnya hampir saja ia menyatakan rahasia tentang Musa, seandainya tidak kami teguhkan hatinya supaya ia termasuk orang-orang yang percaya".

22 Ismail Ibrahim, Mu'jām alfâd wa a'lām al- Quraniyah, Juz II (Kairo: Dâr al-Fikr al-Arabī, 1968), Cet. 2, 101.

${ }^{23}$ Abi Abdullah Muhammad bin Ahmad al-Qurtubi, Al-jamî' al- Ahkâm al-Qur'an, Juz II (Kairo: Dār Kutūb al-Arabī, 1967), 412.

24 Ja'far Muhammad bin Jarīr at-Ṭabari, Tafsîr at-Tabari, Juz II (Beirut: Dār al-Fikr, 1978), 164.

Jurnal Pendidikan Agama Islam (Journal of Islamic Education Studies)

Volume 5 Nomor 2 (2017)

ISSN(p) 2089-1946\& ISSN(e) 2527-4511

Hal. 320 - 338 
Kata Fu'ad identik dengan Qalb yang terkait dengan keteguhan seorang dalam kehidupan dunia dan tidak ada kegundahan hatinya, tidak ada kejelekan pada dirinya, ia bersikap tenang dan tidak emosional. Jadi pada dasarnya Fu'ad dapat dimaknai sebagai orang yang mampu mengendalikan diri, dapat mengontrol emosionalnya sehingga dia dapat bersikap tenang dalam menghadapi setiap persoalan yang menimpa dirinya.

\section{Al-Hilm}

Kata Hilm jamaknya ahlâm dalam al-Qur'an bermakna daya pikir. Secara terminilogi orang yang mampu memfungsikan Hilm ini keadaan jiwanya menjadi tenang, tidak mudah marah dan suka memaafkan. (QS.Al-Fajr:27-30). Sedangkan al-Qurtubi berpendapat, bahwa Aql lebih luas cakupannya dari Hilm, Ia menyamakan "hilm" dengan "dhihn" dalam hal pengetahuan, sedangkan "aql" merupakan potensi yang membedakan kategori pengetahuan yang berbeda itu. Pada dasarnya Hilm merupakan potensi yang ada kehidupannya. Dengan Hilm manusia dapat bersikap tenang dalam menyikapi segala sesuatu, tidak bersikap emosinal serta bijaksana dalam bertindak.

5. Al-Hijr dan Al-Nuhyah

Kedua kata ini punya konotasi makna sama, yaitu menunjuk pada "daya kemampuan nalar", hanya bedanya Hijr berfungsi untuk menjaga supaya tidak tercampur antara yang baik dan buruk, sedangkan Nuhyah berfungsi untuk menjaga dari hal yang tidak baik. Al- Qur'an menjelaskan kedua kata ini dalam surat al-Fajr: 5 dan surat Thâha: 54: " Pada hal-yang demikian itu terdapat sumpah (yang dapat diterima oleh orang-orang yang berakal (dhi Hijr)”. " ..terdapat tanda-tanda kekuasaan Allah bagi orang yang berakal (uli Nuha)". Dari sini dipahami, bahwa sesorang dikatakan "dhi al-Hijr" (mempunyai nalar) dan "Uli al-Nuha" (mempunyai daya rasional) adalah orang yang mengetahui dan menjaga kebaikan dan keburukan dari kehidupannya, mengetahui apa yang sebaiknya dilakukan menurut daya rasionalnya.

6. Al-Syu'ur

Kata Syu'ur bermakna perasaan, kesadaran, kecerdasan. yang dalam al-Qur'an banyak dipakai dengan bentuk jamak, tidak kurang dari 16 surat yang mencantumkannya. Kata Syu'ur dalam al-Qur'an banyak dipakai dan dikaitkan dengan perasaan senang dan penderitaan. (QS.al-A'Râf: 95). Kata Syu'ur juga banyak dipakai dalam kaitannya dengan kesadaran akan kebersamaan tentang kesenangan dan penderitaan. Syu'ur dalam al-Qur'an menunjuk pada aspek rohani manusia yang memungkinkan manusia dapat berfikir, bernalar, sadar akan diri dan kehidupannya merupakan salah satu kelebihan manusia yang mampu berfikir dan berbuat.

7. Al-Ruh 
Kata Ruh terulang dalam al-Qur'an sebanyak 24 kali dengan berbagai konteks dan makna di antaranya menunjukkan "pemberian hidup" (QS.AlHijr:29 dan Al-Sajdah: 9), Penciptaan manusia (QS. Maryam: 17 dan AlAnbiyâ:91). Mengkaji tentang keberadaan ruh itu sangat sulit karena dalam alQur'an sendiri kata Ruh dipakai dalam makna yang beraneka ragam seperti QS. al- Mukmin:16, al-Mujadalah: 22, sehingga sulit untuk mengetahui artinya secara pas apalagi bicara tentang substansinya. ${ }^{25}$

Al-Ghazali membagi rûh dalam dua kategori, yaitu Rûh yang bersifat jasmani; Rûh merupakan bagian dari jasmani manusia, yaitu zat yang halus yang bersumber di ruangan hati (jantung) yang menjadi pusat semua urat (pembuluh darah) yang mampu menjadikan manusia hidup dan bergerak serta dapat merasakan berbagai rasa. Rûh yang bersifat Ruhani. Rûh merupakan bagian dari ruhani yang bersifat halus dan ghaib. Dengan rûh ini manusia dapat mengenali dirinya, mengenal Tuhannya, mampu mencapai ilmu yang bermacam-macam. Rûh ini juga menyebabkan manusia menjadi berprikemanusiaan dan berahlak baik. Dari sini dapat dipahami bahwa ruh merupakan sesuatu yang dapat mengarahkan perilaku dan perbuatan manusia, dapat mendengar, melihat, berkesadaran, berfikir dan berpengetahuan.

8. Al-Aql

Kata Aql dalam bentuk masdar, isim dan amar tidak ada dalam al-Qur'an hanya dipakai dalam bentuk kata kerja ( $f$ ' $\left.^{\prime} \mathrm{l}\right)$, disebut sebanyak 49 kali dalam al-Qur'an. Kata Aql secara bahasa pada bermakna "pengikat" atau "penghalang". Al-Qur'an menggunakannya bagi seseorang yang mengikat atau menghalangi seseorang terjerumus ke dalam kesalahan atau dosa. ${ }^{26}$

25 Ibnu Kathï menyatakan, bahwa Ruh itu adalah pokok dan materi jiwa, dan jiwa terdiri atasnya, melekatlah rûh dengan badan, dilihat dari satu segi Ruh adalah jiwa Muhammad". AlQurtubi dalam "al-Jami' al-Ahkam al-Qur'an" menyatakan: "Samarnya makna Ruh dalam ayat al-Qur'an ini menunjukkan bahwa penciptaan Rûh merupakan perkara yang amat besar, oleh Allah Ruh sengaja disamarkan dan tidak diperjelas agar manusia diyakinkan akan ketidakmampuan dirinya mengakui hakikat dirinya sendiri, padahal ia tahu ada rûh dalam dirinya, ia akhirnya menyadari ketidakmampuan dirinya mengetahui hakikat zat penciptanya yang hak. Hikmanya adalah ketidakmampuan akalnya untuk mengetahui mahkluk yang mendampinginya $(R u h)$ merupakan bukti nyata ketidakmampuannya sama sekali untuk mengetahui zat Khaliq-nya". Muhamad Saltut mengatakan bahwa rûh adalah sesuatu kekuatan yang menyebabkan kehidupan benda-benda, tumbuhan dan manusia. Dengan rûh manusia dapat bergerak, berfikir. Ia sulit diungkap, tetapi keberadaannya dapat dirasakan. Software The Holly Qur'ān versi 7.10, Harf Information Tecnology tahun 2000. Lihat M. Fazlur Rahman, Indeks al-Qur'ān (Jakarta: Amzah, 2009).Lihat pula Fuad Abdul Baqi, Mu'jam alMufahrās li alfẩd al-Qur'ān (Kairo: Dar al-Fikr, 1992), serta CD Software Maktabah al-Sāmilah; akbār mausū'ah al-Islamiyyah, Ihdhar Thani.

${ }^{26}$ Al-Qur'an menjelaskan Aql pada QS. Al-Ankabut:43: "Dan perumpamaan-perumpamaan ini, Kami buatkan untuk manusa dan tiada yang memahaminya kecuali orang-orang yang

Jurnal Pendidikan Agama Islam (Journal of Islamic Education Studies)

Volume 5 Nomor 2 (2017)

ISSN(p) 2089-1946\& ISSN(e) 2527-4511

Hal. 322 - 338 
Secara kontekstual Aql merupakan daya untuk memahami dan menggambarkan sesuatu (QS. al-Ankabut: 43). Daya manusia dalam hal ini berbeda-beda sebagaimana diisyaratkan al-Qur'an antara lain dalam QS: alBaqarah :161. Aql merupakan daya untuk mengambil pelajaran dan kesimpulan serta hikmah (QS. al-Mulk: 10). Aql dalam hal ini diberi kemampuan untuk memahami, menganalisa dan menyimpulkan serta dorongan moral yang disertai dengan kematangan berfikir.

Daya-daya dan potensi Aql diposisikan sebagai obyek pendidikan yang harus dikembangkan dan dipupuk supaya dapat menjadi unsur yang penting bagi kehidupan manusia, karena bila Aql ini tidak dikembangkan maka tujuan pendidikan akan sulit dicapai. Daya dan potensi manusia akan menempatkan manusia pada kedudukan yang mulia di sisi Allah, baik menjadi abdullah maupun khalifah Allah di muka bumi. ${ }^{27}$

berilmu(aql)”. QS Al-An'âm : 151: “Katakanlah, marilah kubacakan atas apa yang diharamkan atas kamu oleh Tuhanmu, yaitu jangan kamu mempersekutukan sesuatu dengan Dia,, berbuat baiklah pada orang tua, jangan kamu membunuh anak kamu karena takut miskin, kami akan memberi rizki kepadamu dan pada mereka, janmganmendekati perbuatan yang keji baik yang nampak atau tersembunyi, dan jangan kamu membunuh jiwa yang diharamkan oleh Allah, melainkan dengan sesuatu yang benar.Demikianlah itu yang diperintahkan kepadamu supaya kamu memahaminya. (aqilun-aql)". Lihat Baqi, Mu'jam al-Mufahrās li alfẫd al-Qur'ān.

${ }^{27}$ Kedudukan dan fungsi manusia di bumi dkonsepkan melalui kata kunci Abdullah dan Khalifa Allah. a) Kata Abdullah orientasi maknanya lebih banyak mengacu pada tugas-tugas individual manusia sebagai hamba Allah. Tugas ini biasanya lebih diwujudkan dalam bentuk pengabdian yang bersifat ritual pada Allah (QS. al-Dariyat:56). Kata abdullah dalam al-Qur'an tidak hanya dipakai untuk kontek manusia saja, tetapi juga untuk malaikat (QS. al-Zukhrûf: 19) serta untuk jin (QS. Al-Dariyât: 58). Kontekualisasi kata abdullah, biasa diartikan sebagai kewajiban, keagamaan sebagai pemenuhan fungsi kehambaan manusia yang lebih cenderung bersifat individual, mengingat tuntutan adanya penghayatan yang dalam agar seorang dapat sampai pada tingkat relegiusitas. Untuk sampai pada tingkat relegiusitas yang tinggi biasanya ditandai kedekatan manusia dengan Allah. Dengan demikian sangatlah sulit mengukur keberagamaan seseorang, mengingat setiap individu akan mempunyai persepsi dan expressi penghayatan yang beragam. Manusia dalam kontek abdullah di tuntut untuk bersikap tawadhu', tidak arogan dan selalu bertawakal pada Allah. Karena esensi abdullah adalah ketaatan, ketundukan, kepatuhan yang semua itu hanya layak diberikan pada Allah saja. Bila dilihat dari esensinya, kedudukan manusia dalam konteks abdullah lebih berindikasi pada ketaatan pada Tuhan, dalam arti aspek hubungan manusia dengan Tuhan lebih domiman. Ini artinya ketaatan adalah kodrat alamiah yang senantiasa berlaku baginya, ia terlihat dengan hukum-hukum Tuhan yang menjadi kodrat pada ciptannya. Dan manusia menjadi bagian dari ciptaannya. b) Kata Khalîfah dalam bentuk tunggal terulang dua kali dalam al-Qur'an (QS. alBaqarah: 30) dan al-Shâd: 26). Makna filosofis dari istilah khalîfah ternyata tidak menimbulkan perbedaan pendapat, namun para ahli berbeda ketika mendifinisikan pandanga mereka. Jika khalîfah diartikan sebagai pengganti maka kita akan berhadapan pada tiga pandangan. Tobroni dan Syamsul Arifin, Islam Pluralisme Budaya dan Politik (Yogyakarta: SiPress, 1994), 152. 


\section{Al-Qalb}

Kata Qalb disebut dalam al-Qur'an dalam bentuk isim mufrad dan jama' di ulang-ulang sebanyak 132 kali. Kata ini terambil dari akar kata yang bermakna "membalik" karena seringkalai ia membolak-balik, sekali susah sekali senang, sekali setuju sekali menolak dan Qalb berpotensi untuk tidak konsisten. Qalb juga dapat diartikan sebagai daya nalar opini, kecerdasan praktis (practical intellegence) atau dalam istilah psikologi dimaknai dengan "kecakapan untuk memecahkan suatu masalah" (problem solving capacity). ${ }^{28}$

Konstekstualisasi ayat menyatakan, bahwa Qalb adalah suatu tempat/wadah kasih sayang dan keimanan. Qalb biasanya menampung hal-hal yang disadari oleh pemiliknya, bila dikaitkan dengan arah katanya yang bermakna berbolak-balik, tidak konsisten maka kasih sayang dan keimanan yang ada pada diri manusia itu juga berubah, dalam arti dapat tidak konsisten, bertambah dan berkurang pada diri manusia. Qalb juga merupakan pusat penalaran dan pemikiran serta kehendak yang berfungsi untuk berfikir, memahami sesuatu (QS. al-A'râf: 179). Di samping itu, Qalb dapat mengetahui hakekat kebenaran dari segala yang ada, dengannya manusia dapat merasakan kedekatannya dengan Tuhan.

\section{Tujuan Pengembangan Etika dan Keperibadian}

Secara spesifik tujuan ethic and personality development di lembaga pendidikan Islam difokuskan pada beberapa hal, yaitu:

\section{Perubahan Perilaku Manusia}

Tujuan ethic and personality development di antaranya adalah merubah perilaku manusia. Mohammad al-Toumy al-Syaibany dalam Falsafah alTarbiyyah al-Islämiyyah yang menjelaskan, bahwa tujuan ethic and personality development adalah perubahan tingkah laku individu dalam kehidupan pribadinya, kehidupan masyarakat dan alam sekitarnya. ${ }^{29}$ Kata kunci dari pikiran al-Syaibani adalah "perubahan". Perubahan yang diinginkan dalam ethic and personality development adalah perubahan yang terkait dengan perilaku individu, perilaku sosial dan perilaku terkait dengan profesionalisme.

\footnotetext{
${ }^{28}$ Kata Qalb terdapat dalam ayat al-Qur'an di antaranya QS. Qâf:37 :" Sesungguhnya pada yang demikian itu bebar-benar terdapat peringatan bagi orang-orang yang mempunyai hati (qalb) atau yang menggunakan pendengarannya, sedang ia menyaksikannya". QS: al-Hadid 27; "dan kami berikan kepadanya injil dan kami jadikan dalam hati (Qalb) orang-orang yang mengikutinya rasa santun dan kasih sayang. Software The Holly Qur'an versi 7.10, Harf information Tecnology tahun $2000 \mathrm{M}$.
}

${ }^{29}$ Omar Toumy al-Syaibany, Falsafah al-Tarbiyyah al-Islämiyyah, Terj. Hasan Langgulung (Jakarta: Bulan Bintang, tt), 397.

Jurnal Pendidikan Agama Islam (Journal of Islamic Education Studies)

Volume 5 Nomor 2 (2017)

ISSN(p) 2089-1946\& ISSN(e) 2527-4511

Hal. 324 - 338 
Pertama, terkait dengan perilaku individu. Perubahan yang diinginkan adalah terletak pada aspek perilaku, aktifitas dan cara pencapaiannya. Perilaku tersebut pada akhirnya dapat mengantarkan mereka pada kehidupan yang diinginkan, baik di dunia dan akhirat. Kedua, terkait perilaku kehidupan sosial, yaitu berkaitan dengan tingkah laku yang berhubungan dengan masyarakat secara keseluruhan dalam kehidupannya. Ketiga, berkaitan dengan kehidupan profesionalismenya, Perubahan yang diharapkan adalah perubahan bidang ilmu pengetahuan yang harus disesuaikan dengan perkembangan zaman, perubahan paradigma profesi dan aktifitas lainnya.

Hal lain yang penting dilakukan dalam perubahan tersebut adalah semaksimal mungkin memanfaatkan aspek psikologi manusia sebagai pintu masuk membangun perubahan etika dan kepribadian manusia, khusunya peserta didik.

2. Memberi Bekal Hidup Manusia

Ethic and personality development bertujuan memberikan bekal yang cukup pada manusia (peserta didik) dalam mengarungi kehidupannya. Pemberian bekal manusia ini di antaranya: ${ }^{30}$ a) Memberi bekal akhlak yang mulia. Akhlak merupakan jiwa bagi perilaku manusia dalam kehidupannya yang berakibat sesorang itu mrndapat "fadilah" (keutamaan) dalam kehiudpannya. Faḍilah yang dimaksud adalah keutamaan akhlak yang harus ada pada setiap materi palajaran serta guru harus memegang teguh akhlak di atas segalanya. b) Memberi bekal keilmuan yang dapat digunakan dalaamkehidupan dunia dan akhirat. Etika dan kepribadian tidak hanya mementingkan kehidupan dunia dengan bekal ilmu pengetahuan semata, tetapi juga mementingkan kehidupan akhirat dengan bekal ilmu agama yang cukup. c) Memberi bekal keterampilan untuk mencari rezeki dengan etika dan perilaku yang baik. d) Memberi bekal motivasi untuk belajar dan menumbuhkan roh ilmiah (scientific spirit) kepada pelajar-pelajar Islam. Roh ilmiah ini merupakan hal yang penting dalam menunjang keberhasilan pendidikan, karena dengan itu manusia dapat mempelajari sesuatu dengan baik, semangat dan hasilnya akan maksimal. e) Memberi bekal profesionalisme setelah lulus dari lembaga pendidikan. ${ }^{31}$ Menyiapkan pelajar supaya ia dapat menekuni profesi tertentu sangat penting supaya ia dapat mencari rezeki dalam hidupnya sekaligus tetap memelihara segi rohani, agama dan akhlaknya,

\footnotetext{
30Muhammad Ațiyah al-Abrasyìi, Al-Tarbiyyah wa al-Falsafātuhā (Kairo:Isa al-Bāb al-Halabi, 1969) dalam al-Syaibany, Falsafah al-Tarbiyyah al-Islämiyyah, 418.

${ }^{31}$ Al-Abrasyi, al-Tarbiyyah al-Islämiyyah, 418.
} 
Ah. Zakki Fuad, Jauharoti Alfin, Ahmad Munjin Nasih

melatih akal dan hati, perasaan, kemauan serta kepribadiannya dalam masyarakat. 32

Pendidikan Islam seharusnya memberikan bekal etika dan kepribadian yang baik kepada manusia supaya dapat tumbuh dengan seimbang melalui latihan spiritual, intelektual, rasionalitas dan kepekaan terhadap manusia. Karena itu, pendidikan seharusnya membukakan jalan bagi pertumbuhan manusia dalam segala aspek spiritual, intelektual, imajinatif, fisikal, ilmiah, linguistik, baik secara individual maupun secara kolektif dan memotivasi semua aspek untuk mencapai kebaikan dan kesempurnaan.

3. Optimalisasi Potensi Manusia

Etika dan kepribadian merupakan hal baik yang dapat digunakan mengembangkan potensi yang dimiliki oleh peserta didik. Al-Nahlawi, menyatakan, bahwa etika dapat dipakai sebagaai alat untuk mengembangkan dan mengoptimalkan potensi akal dan pikiran untuk menyongsong kehidupan manusia dan merenungkan, memahami segala yang diciptakan oleh Allah di semesta alam, alat mengembangkan dan menumbuhkan potensi bakat yang dimiliki mulai dari taman kanak- kanak sampai menjad manusia dewasa. ${ }^{33}$

\section{E. Metode Membangun Etika dan Kepribadian}

Membangun etika dan kepribadian memerlukan metode yang beragam yang harus disesuaikan dengan karakteristik peserta didik. Beberapa metode yang spesifik digunakan membangun etika dan kepribadian dalam tulisan ini dibagi menjadi dua kategori, yaitu; 1) Metode yang dikemukakan oleh para pakar psikologi pendidikan Islam. Metode ini bertujuan membangun etika dan kepribadian melalui teori-teori pembelajaran di kelas/ sekolah. 2) Metode yang ditemukan dari hasil riset yang dilakukan penulis di Lembaga Pendidikan. Metode ini berusaha membangun etika dan kepribadian melaui praktik langsung di lapangan.

Metode pembangunan etika dan kepribadian yang dikemukakan oleh pakar psikologi pendidikan Islam, di antaranya:

1. Metode Keteladanan (Al-Uswah)

Metode keteladanan (al-Uswah) digunakan dalam membentuk karakter, akhlak yang baik bagi peserta didik. Realitas yang terjadi pada kegiatan belajar

32 Fadil al-Jamali mengemukakan, bahwa etika dan kepribadian diajarkan kepada manusia supaya memahami tanggung jawabnya sebagai individu dalam hidup ini, memahami tanggung jawabnya dalam sistem sosial masyarakat, memahami dan memperlakukan alam semesta dan memanfaatkannya untuk kehidupan dengan baik. Muhammad Fadil al-Jamali, AlFalsafah al-Tarbiyyah fi al-Qur'an (Beirut: Dār al-Kitāb al-Jadid, 1966), 420.

${ }^{33} \mathrm{Abd}$ Rahman al-Nahlawi, Usūs al-Tarbiyyah wa al-Turūq al-Tadrīisuhā (Damaskus: Dār al-Fikr, tt), 163-164.

Jurnal Pendidikan Agama Islam (Journal of Islamic Education Studies)

Volume 5 Nomor 2 (2017)

ISSN(p) 2089-1946\& ISSN(e) 2527-4511

Hal. 326 - 338 
mengajar, baik di kelas maupun di luar kelas membuktikan, bahwa seorang yang sedang belajar punya kecenderungan meniru prilaku yang dilakukan oleh seorang pengajar (guru), pengaruh guru sangat kuat dalam membentuk akhlak dan kepribadian, maka wajib bagi guru untuk memberikan keteladanan akhlak dan kepribadian yang baik. ${ }^{34}$

Akhlak dan kepribadian diajarkan melalui keteladanan dengan cara memberikan contoh prilaku yang baik, sifat yang luhur, cara berpikir yang positif dan lain-lain. ${ }^{35}$ Nasih Ulwan menyatakan, bahwa pendidikan akhlak melalui keteladanan merupakan metode yang paling efektif, penting, dan berhasil. Hal itu karena dalam belajar, orang (peserta didik) pada umumnya, lebih mudah menangkap sesuatu hal yang konkrit daripada abstrak, artinya pendidik lebih mudah menyampaiakan pesannya secara lisan dengan disertai contoh kongkrit melalui dirinya sendiri (guru). ${ }^{36}$

Metode ini bisa digunakan membangun etika berbicara dengan baik. Parameternya adalah firman Allah dalam Al-Qur'an, 17: 53. Al-Qur'an, 14: 26. Hal-hal yang termasuk dalam kalimat yang baik ialah kalimat tauhid, segala ucapan yang menyeru kepada kebajikan dan mencegah dari kemungkaran serta perbuatan yang baik. Sedangkan Ayat-ayat yang terkait dengan perkataan yang baik di antaranya: Al-Qur'an, 17: 53. Keutamaan bicara baik, Al-Qur'an, 22: 24, 35: 10. Perkataan baik dan buruk: Al-Qur'an, 14: 24, 14: 25, 14: 26, 24 : 26, 28: 55, 39: 18. Perkataan yang benar: Al-Qur'an, 33: 32, 33: 70. Etika berbicara yang baik: Al-Qur'an, 31: 19, 49: 3.Al-Qur'an, 14: 26.

2. Metode Pembiasaan

Pembiasaan merupakan metode langsung yang berusaha mengintegrasikan antara ilmu pengetahuan teoritis dan praktik di lapangan, hal ini bertujuan menjaga keseimbangan antara pengetahuan dan teori dengan praktiknya. ${ }^{37}$ Pembiasaan merupakan proses penanaman kebiasaan.

\footnotetext{
${ }^{34}$ Abuddin Nata, Pemikiran Para Tokoh Pendidikan Islam; Suatu Kajian Filsafat Pendidikan Islam (Jakarta: Raja Grafindo Persada, 2003), 74-76.

35 Parameter keteladanan yang paling tinggi adalah QS, Al-Ahzab: 21. "Sesungguhnya pada diri Rasulullah terdapat suri tauladan yang baik". Prilaku Nabi Muhammad adalah interpretasi dan bersumber dari al-Qur'an, mulai dari cara beribadah, cara berkehidupan sehari-haripun harus meneladani kehidupan Nabi yang Islami.

${ }^{36}$ Abdullah Nasih 'Ulwan, Tarbiyah al-Aulād fi al-Islām (Beirut: Dār as-Salām, t. t.), 632.

37 Hasan Al-Banna, Majmu' Al-Rasail al-Imam as-Syahid Hasan Al-Banna (Kiro: Dār al-Da'wah, $141 \mathrm{H})$, 58. Al-Banna juga memberikan catatan, bahwa metode akan bisa dilaksanakan dengan baik jika ada sistem pendidikan yang mendukung. Sistem itu meliputi; katibah, usrah, mu'tamar dan daurah.
} 
Kebiasaan (habit) ialah cara-cara bertindak yang otomatis (tanpa disadari oleh pelakunya). ${ }^{38}$

Metode Pembiasaan efektif dilakukan untuk membangun akhlak dan kepribadian, apalagi dilakukan terhadap peserta didik yang masih kecil (Taman Kanak-kanak, Madrasah Ibtidaiyah), hal disebabkan mereka memiliki memori yang kuat dan kondisi kepribadian yang belum matang, sehingga mereka mudah terlarut dengan kebiasaan-kebiasaan yang mereka lakukan sehari-hari. Metode pembiasaan merupakan cara yang sangat efektif dalam menanamkan nilai-nilai akhlak/etika, kepribadian kejiwa peserta didik. Nilainilai yang sudah dibiasakan akan secara otomatis berpengaruh terhadap kehidupannya sampai dewasa.

Metode ini bisa digunakan dalam membangun prilaku istikamah dalam kehidupan sehari-hari. Perilaku ini parameternya adalah Allah dalam AlQur'an, 46: 13, Al-Qur'an, 41: 30. Ayat-ayat Al-Qur'an lain yang yang menjelaskan tentang pentingnya istikamah adalah: Al-Qur'an, 10: 89, 11: 112, 41: 6, 42: 15, 45: 118, 46: 18.

3. Metode Kisah (Qisah) al-Qur'ān Wa al-Nabawī

Etika dan kepribadian dapat dibangun melalui metode Qisah al-Qur'ān Wa al-Nabawi, yaitu menceritakan kisah-kisah dalam al-Qur'an dan kehidupan nabi Muhammad yang terkait dengan akhlak dan kepribadian. Al-Qur'an banyak menceritakan tentang akhlak yang baik, seperti lukman al-Hakim, ashāb al-Kahfi dan lainnya. Akhlak Nabi melalui sirāh nabawījuga menjadi kisah yang baik dalam membangun prilaku peserta didik. ${ }^{39}$

Metode kisah (cerita) mempunyai fungsi edukatif yang tidak dapat diganti dengan bentuk penyampaian lain selain dalam bentuk bahasa. Hal ini disebabkan kisah memiliki beberapa keistimewaan dan pengaruh psikologisedukatif sekaligus mampu melahirkan kehangatan perasaan dan vitalitas serta aktivitas di dalam jiwa, memotivasi peserta didik untuk mengubah prilakunya, memperbaharui tekadnya sesuai dengan tuntunan, pengarahan serta pengambilan pelajaran ('ibrah).

Metode ini bisa digunakan untuk membangun etika sosial bersedekah dan infak untuk menolong sesama. Ukuran etika sosial adalah firman Allah dalam Al-Qur'an, 4: 114, Al-Qur'an, 58:13. Ayat-ayat lain tentang pentingnya

\footnotetext{
38 Noer Aly, Ilmu Pendidikan Islam (Jakarta: Logos Wacana Ilmu, 1999), 184.

${ }^{39}$ Cerita (qisah) yaitu tuturan yang membentangkan bagaimana terjadinya suatu hal (peristiwa, kejadian dan sebagainya). Lihat Puerwodarminta, Kamus Bahasa Indonesia (Jakarta: Balai Pustaka, 2002), 202. Cerita/kisah dalam bahasa arab “qiṣah" bentuk jamaknya "qașaș". Cerita dalam bahasa Inggris adalah story tale dan narrative. Lihat Ahmad Warson Munawwir, AlMunawwir; Kamus Arab - Indonesia (Surabaya: Pustaka Progressif, 2002), 1126.
}

Jurnal Pendidikan Agama Islam (Journal of Islamic Education Studies)

Volume 5 Nomor 2 (2017)

ISSN(p) 2089-1946\& ISSN(e) 2527-4511

Hal. 328 - 338 
infak di antaranya: Al-Qur'an, 2: 254, 2: 261, 3: 17, 3: 92, 3: 18, 14: 31, 17: 29, 25: 67, 26: 88, 32: 16, 35: 24, 36: 47, 42: 38, 51: 19, 57: 7, 57: 10, 57: 11, 57: 18, 63: 10. 64: 16, 64: 17, 73: 20, 107: 3.

4. Metode Nasihat (Al-Nasīhah)

Nasihat merupakan salah satu metode dalam pendidikan yang sering digunakan dalam membentuk akhlak dan prilaku peserta didik, bahkan setiap pembelajaran yang dilakukan di kelas maupun di luar kelas tidak bisa dilepaskan dari metode ini. Nasihat bermakna memberikan penjelasan tentang kebaikan, kebenaran dan kemashlahatan dengan tujuan menjadikan orang yang diberi nasihat menjadi lebih baik, lebih bahagia, lebih sukses dan lainnya.

Metode nasihat merupakan metode penting dalam pendidikan akhlak, hal ini karena pendidik dapat menanamkan pengetahuan yang baik ke dalam jiwa peserta didik dengan cara mengetuk relung jiwa yang paling dalam. Metode nasihat mampu mengarahkan peserta didik kepada arah kebaikan dan kemaslahatan serta kemajuan masyarakat secara umum. ${ }^{40} \mathrm{Hal}$-hal yang perlu diperhatikan adalah teknik penyampaian nasihat yang harus fleksibel supaya dapat diterima dengan baik.

5. Metode Targhīb Wa al-Tarhīb

Metode targhīb (reward) dan tarhīb (punishment) yaitu metode pembelajaran yang dilakukan dengan cara memberikan hadiah, penghargaan bagi yang berhasil melakukan sesuatu serta memberikan peringatan, hukuman bagi yang melanggar sesuatu yang sudah ditetapkan. ${ }^{41}$ Implementasi metode ini dalam membangun etika dan kepribadian dilakukan dengan cara menetapkan etika dan kepribadian melalui kontrak belajar, tata tertib dan kesepakan-kesepakatan bersama di lembaga pendidikan maupun di masyarakat. Bagi peserta didik yang mampu melaksanakan aturan, tata tertib dan kesepakatan yang dibangun bersama akan mendapatkan penghargaan, hadiah sebagai reward atas prilakunya. Sedangkan bagi peserta didik yang melanggar ketentuan, tata tertib atau tidak mengerjakan kesepakatan-

40 Muhammd Munir Mursa, Al-Tarbiyah al-Islamiyyah: Ushuluhā wa Tathawwuruhā fĭ al- Bilād al'Arabiyyah (Kairo: 'Alām al-Kutūb, 1977), 55.

${ }^{41}$ Targhīb wa al-Tarhīb perspektif pendidikan Islam berbeda dengan metode Reward and Punishment. Letak perbedaannya ialah metode Targhib wa al-Tarhib bersumber dari tata aturan dari Al-Qur'an dan Nabi Muhammad, sedangkan Reward and Punishment bersumber dari kesepakatan-kesepakatan manusia. Seperti khaf kepada Allah (QS. 3: 175; 55: 46; 7: 5556), khusyu', perasaan rendah hati, tunduk, kepada, Allah swt (QS. 57: 16 dan 39: 23), perasaan cinta (QS. 2: 165; 3), harapan mendapatkan pahala (QS. 2: 218). Lihat Muhammad Quthb, Sistem Pendidikan Islam (Bandung: al-Ma'arif, 1993), 340. 
kesepakatan bersama akan di berikan hukuman dan peringatan supaya timbul perubahan prilaku yang lebih baik.

6. Metode Tadarrūj wa al-Tikrarī (Pentahapan dan Pengulangan)

Metode pentahapan (tadarrujj) digunakan untuk memberikan pengetahuan, perilaku kebaikan kepada peserta didik secara bertahap dan berangsur-angsur supaya pengetahuan yang diberikan bisa dipahami dan diserap dengan baik. Metode pengulangan (tikrarī) yaitu mengulang setiap kegiatan, perilaku, pengetahuan, materi yang diberikan kepada peserta didik pada akhir pelajaran dengan cara ulangan, ujian, evaluasi, penialain. Hal ini tujuaannya agar peserta didik mampu memahami ilmu pengetahuan, kegiatan pembelajaran yang diajarkan secara baik. ${ }^{42}$

Metode Tadarrüj wa al-Tikrarī (Pentahapan dan Pengulangan) bisa digunakan dalam membangun etika dan kepribadian karena etika dan kepribadian itu tidak bisa instan diberikan kepada peserta didik melainkan harus bertahap berulang-ulang supaya hasilnya bisa maksimal merasuk ke dalam setiap prilaku peserta didik. Metode ini juga bisa digunakan untuk membangun prilaku pemaaf dalam kehidupan sosial kemasyarakatan. Hal ini identik dengan firman Allah Al-Qur'an, 2: 263, Al-Qur'an, 42: 37. Ayat-ayat di atas menjelaskan tentang pentingnya pemberian maaf kepada orang lain dalam kehidupan bermasyarakat. Oleh karena itu melalui metode ini diharapkan mencetak peserta didik yang mempunyai jiwa pemaaf dan generasi yang menjauhi permusuhan, tawuran, dendam antara sesama manusia supaya kehidupan beragama dan bernegara bisa maju.

Selanjutnya adalah beberapa metode yang merupakan hasil riset yang dilakukan di beberapa lembaga pendidikan Islam untuk membangun etika dan kepribadian peserta didik, di antaranya; safari Ramadhan, kesenian Islami (Banjari dan Qasidah), salat jama'ah, istighasah, kepramukaan, silaturahmi, bakti sosial. ${ }^{43}$

1. Safari Ramadhan

Safari Ramadhan merupakan program tahunan yang dilaksanakan sekali dalam satu tahun. Pelaksanaannya pada bulan Ramadhan. Bentuk kegiatan Safari Ramadhan ini berupa pendelegasian peserta didik ke berbagai desa

42 Ibnu Khaldun, Al-Mukaddimah Ibn Khaldun, Terj. Thoha (Jakarta: Pustaka Firdaus, 2001), 757. Bandingkan dengan Jawwad Ridha, Tiga Aliran Utama Teori Pendidikan Islam (Yogyakarta: Tiara Wacana, 2002), 191.

43 Riset dilakukan oleh Ah. Zakki Fuad dan Suparto dengan judul "Pembangunan Etika dan Kepribadian melalui Integrasi Kompetensi Spiritual (K-1) dan Kompetensi Sosial (K-2) di Lembaga pendidikan Islam Kab. Lamongan". Tahun 2017 bekerja sama dengan Pusat Penelitian UIN Sunan Ampel Surabaya. Sampel penelitian; SMA NU I Model, Mts Tanwirul Qulub, MI Sunan Drajad Lamongan, Mi YPPI 45 Lamongan.

Jurnal Pendidikan Agama Islam (Journal of Islamic Education Studies)

Volume 5 Nomor 2 (2017)

ISSN(p) 2089-1946\& ISSN(e) 2527-4511

Hal. 330 - 338 
sekitar untuk menjadi imam shalat tarawih sekaligus memberikan tausiah dalam bentuk kultum setiap selesai shalat tarawih atau menjadi makmum pada masjid-masjid secara berjamaah. Tujuan kegiatan ini adalah membimbing peserta didik dan berinteraksi langsung dengan masyarakat supaya memiliki perilaku dan akhlak yang baik, percaya diri, dan bertanggung jawab dalam berinteraksi secara efektif dengan lingkungan sosial dan alam serta dalam menempatkan diri sebagai cerminan bangsa dalam pergaulan dunia. Dalam dimensi pengetahuan, kegiatan ini dapat memberikan bekal ilmu pengetahuan, khususnya ilmu agama dan sosial serta dapat menambah wawasan kemanusiaan bagi peserta didik. Dalam dimensi keterampilan, kegiatan Safari Ramadhan ini mampu memotivasi peserta didik untuk memiliki kemampuan pikir dan prilaku yang efektif dan kreatif saat melakukan pengabdian di masyarakat sebagai pengembangan dari yang dipelajari di sekolah secara mandiri. ${ }^{44}$

2. Shalat Berjamaah

Kegiatan shalat berjamaah merupakan kegiatan harian yang dilakukan di lembaga pendidikan (shalat dhuha, dhuhur, asyar) setiap hari tujuannya adalah menanamkan kepribadian spiritualis, menumbuhkan rasa kebersamaan, menanamkan dan menumbuhkan etika disiplin, tumbuhnya rasa kebersamaan akan membawa dampak positif dalam kepribadian seseorang. Beberapa dampak positif tersebut di antaranya yaitu menumbuhkan semangat bergotong royong, saling membantu, ikatan kekerabatan,kekompakan,solidaritas.

3. Istighathah dan Tahlil

Kegiatan istighatsah merupakan kegiatan harian. Kegiatan ini dilaksanakan setiap hari di pagi hari sebelum pelaksanaan kegiatan belajar dan pembelajaran dimulai, durasi waktu sekitar 10-15 menit. Kegiatan ini langsung dipandu dari kantor sekolah melalui pengeras suara, sedangkan pendidik yang mempunyai jam awal melakukan pendampingan terhadap peserta didik di kelas. Kegiatan istighatsah dan tahlil ini bertujuan menanamkan dan menumbuhkan sikap menghargai terhadap orang-orang yang telah berjasa yang telah meninggal dunia, menanamkan dan menumbuhkan sifat serta sikap rendah hati dan rendah diri. Sikap menghargai terhadap orang-orang yang

44 Hasil yang dicapai setelah kegiatan ini di antaranya yaitu peserta safari Ramadhan mempunyai etika berkomunikasi dengan baik, karena materi yang harus dikuasai adaah etika berkata dengan sopan dan santun sesuai dengan al-Qur'an; "Qaulan Sadida" (QS. An Nisa: 9), "Qaulan Ma'rufa" (QS. An Nisa: 5), "Qaulan Baligha" (QS. An Nisa: 63), "Qaulan Maysura" (Al Isra: 28), "Qaulan Layyina" (QS. Thaha: 20), “Qaulan Karima” (QS. Al Isra: 23). 
telah berjasa yang telah meninggal dunia tecermin melalui kegiatan tahlil. Dengan sikap mau mendoakan terhadap orang yang telah meninggal dunia, seseorang berarti masih mengingat budi baik atau jasa ,meneladani perbuatan positif para pendahulunya.

4. Seni Islami (Shalawat Banjari dan Qasidah)

Kegiatan seni Islami pada dasarnya merupakan kegiatan mingguan yang dilakukan satu minggu sekali dalam bentuk latihan rutin. Seni Islami merupakan kegiatan membaca shalawat kepada nabi Muhammad dengan cara dilagukan dan diiringi dengan alat musik tradisional yang disebut Terbang. Tujuan kegiatan ini adalah menanamkan kecintaan terhadap kebudayaan, kecintaan terhadap Rasulullah Muhammad, berinteraksi dan berkomunikasi yang baik dengan masyarakat sekitar.

5. Kepramukaan

Kepramukaan merupakan kegiatan kepanduan. Kegiatan ini melatih dan membekali peserta didik dengan dasar-dasar menjadi seorang pemimpin. Kegiatan kepramukaan merupakan kegiatan ekstrakurikuler wajib dalam sebuah lembaga pendidikan mulai dari tingkat dasar sampai tingkat menengah. Pendidikan kepramukaan adalah proses pembentukan kepribadian, kecakapan hidup, dan akhlak mulia pramuka melalui penghayatan dan pengamalan nilainilai kepramukaan. Nilai-nilai kepramukaan tersebut terdeskripsikan dalam tri satya dan dasa darma pramuka (untuk pramuka penggalang, penegak, dan pandega) atau dwi satya dan dwi darma (untuk pramuka siaga).

6. Silaturahim

Silaturrahim adalah menjalin hubungan kekerabatan. Di Lembaga Pendidikan Islam, silaturahim diwujudkan dalam beberapa bentuk kegiatan. Beberapa bentuk kegiatan tersebut di antaranya yaitu menjenguk peserta didik yang sakit, menghadiri undangan peserta didik, dan berta'ziah ke rumah peserta didik yang keluarganya meninggal dunia, datang ke rumah guru. Tujuan kegiatan ini adalah membangun etika dan kepribadian yang terkait dengan hubungan antar manusia, seperti sikap peduli terhadap teman yang sakit, takziyah, datang ke rumah guru termasuk perbuatan mempererat persaudaraan, perbuatan ini akan membentuk hubungan kekerabatan yang berujung pada rasa saling memiliki, menyayangi, dan mencintai satu sama lain.

7. Bakti Sosial

Bakti sosial termasuk program kegiatan bulanan di Lembaga Pendidikan Islam. Kegiatan ini dilaksanakan pada bulan-bulan khusus, seperti bulan Muharam, Ramadhan, dan Dzulhijjah. Selian itu kegiatan ini pelaksanaannya bersifat momentum, yaitu ketika terjadi musibah pada daerah dan masyarakat tertentu. Bentuk kegiatan ini dapat dibedakan dalam beberapa 
bagian. Beberapa bentuk bagian kegiatan tersebut di antaranya yaitu: kerjabakti di masjid dan santunan anak yatim (bulan Muharram), kerjabakti di masjid dan pembagian zakat fitrah (bulan Ramadhan), penyaluran daging kurban (bulan Dzulhijjah) dan memberikan bantuan kepada korban bencana alam. Bentuk-bentuk kegiatan bakti sosial bertujuan membangun kepribadian saling peduli antara umat manusia, gemar berzakat dan bersedekah serta gemar menjaga kebersihan dan keindahan. Kegiatan ini dapat dikaitkan sebagai implementasi dari nilai-nilai religius yang terkandung dalam ajaran agama Islam.

\section{F. Skema Teoritik Membangun Etika dan Kepribadian di Lembaga Pendidikan Islam Perspektif Psikologi Qur'ani}

Etika dan keperibadian (ethic and personality) punya kedudukan sangat penting karena merupakan salah satu indikator keberhasilan pendidikan, kemajuan dan harmonisasi masyarakat banyak ditentukan etika dan keperibadian warga masyarakatnya. Hal ini merupakan tanggung jawab lembaga pendidikan untuk membekali peserta didiknya dengan etika dan kepribadian yang baik. Berikut ini skema teoritik pengembangan etika dan kepribadian di lembaga pendidikan Islam:

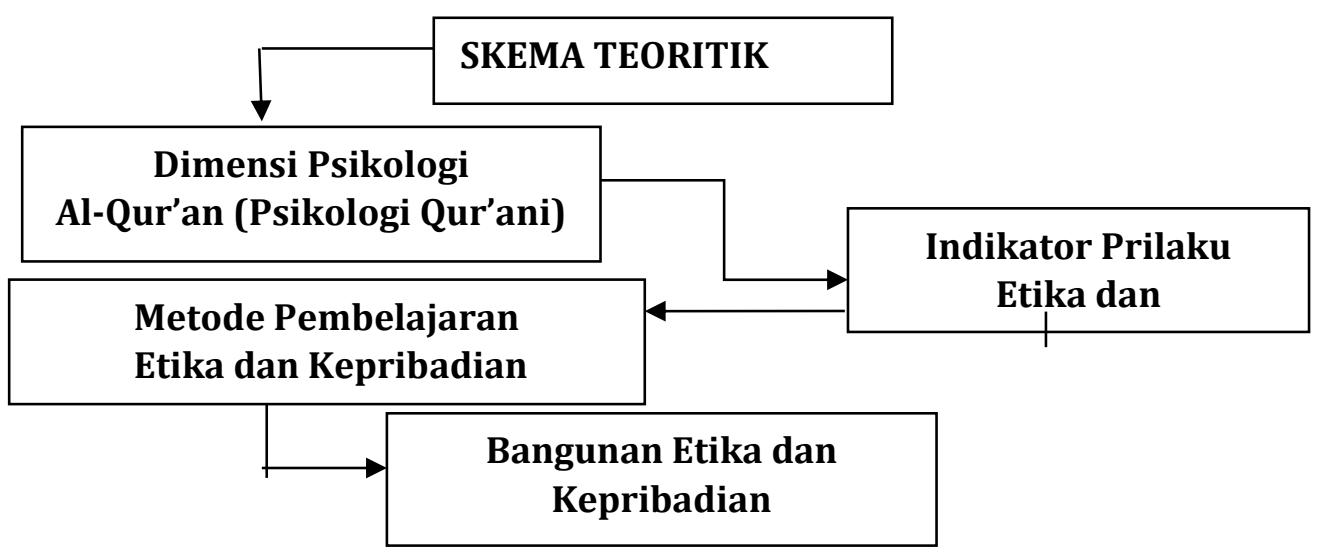

Al-Qur'an menawarkan konsep psikologi melalui berapa kata kunci dalam ayat dan surat yang berbeda. Penelitian dengan pendekatan tematik dan Content Analysis menemukan kata kunci yang dipakai dalam memahami psikologi manusia beserta indikator prilaku etika dan kepribadiannya, yaitu:

\begin{tabular}{|c|c|}
\hline $\begin{array}{c}\text { Dimesi Psikologi Al-Qur'an } \\
\text { (Psikologi Qur'ani) }\end{array}$ & Indikator Prilaku Etika dan Kepribadian \\
\hline & - Emosional \\
$A l-N a f s$ & - Lemah lembut \\
\hline
\end{tabular}


Ah. Zakki Fuad, Jauharoti Alfin, Ahmad Munjin Nasih

\begin{tabular}{|c|c|}
\hline & $\begin{array}{ll}\text { - } & \text { Kecenderungan baik dan buruk } \\
\text { - } \quad \text { Kemauan berbuat baik }\end{array}$ \\
\hline$A l-L u b b$ & $\begin{array}{ll}\text { - } & \text { Rasional } \\
\text { - } & \text { Cerdik }\end{array}$ \\
\hline Al-Fu'ad & $\begin{array}{ll}\text { - } & \text { Keteguhan hati } \\
\text { - } & \text { Emosional } \\
\text { - } & \text { Mengendalikan diri }\end{array}$ \\
\hline Al-Hilm & $\begin{array}{l}\text { - } \text { Pemaaf } \\
\text { - Jiwa yang tenang } \\
\text { - } \quad \text { Bijaksana }\end{array}$ \\
\hline Al-Hijr-Al-Nuhyah & $\begin{array}{l}\text { - Nalar kebaikan } \\
\text { - Daya Rasional }\end{array}$ \\
\hline Al-Ruh & $\begin{array}{ll}\text { - } & \text { Kesadaran diri } \\
\text { - } & \text { Berpikir } \\
\text { - } & \text { Mendengar } \\
\text { - } & \text { Melihat }\end{array}$ \\
\hline$A l-A q l$ & $\begin{array}{ll}\text { - } & \text { Memahami } \\
\text { - } & \text { Menganalisa } \\
\text { - } & \text { Menggambarkan } \\
\text { - } & \text { Mengambil pelajaran } \\
\text { - } & \text { Menalar }\end{array}$ \\
\hline Al-Qalb & $\begin{array}{ll}\text { - } & \text { Nalar } \\
\text { - } & \text { Beropini } \\
\text { - } & \text { Kecerdasan Praktis (Practical } \\
& \text { Intelgency) } \\
\text { - } & \text { Problem solving capacity } \\
\text { - } & \text { Tempat kasih sayang } \\
\text { - } & \text { Wadah keimanan } \\
\text { - } & \text { Hakikat Kebenaran }\end{array}$ \\
\hline
\end{tabular}

Dimensi Psikologi dan Indikator Prilaku Etika dan Kepribadian dapat diimplemantasikan dalam kegiatan belajar mengajar dengan menggunakan teori belajar psikologi yang sesuai. Pakar Psikologi mengemukakan beberapa metode pembelajaran untuk mengembangkan aspek psikologis peserta didik, di antaranya; Connectionism theory, Classical Conditioning, Operant Coditioning, Contiguous Conditioning, Cogitive theory dan Social Learning Theory. ${ }^{45}$ Para pakar

45 Teori-teori ini dikembangkan oleh Edward L.Thorndike, Ivan Pavlov, Frederic Skinner, Edwin R. Guthrie, Albert Bandura yang berkembang pada era klasik sampai modern. a) Connectionism Theory (Edward L.Thorndike) atau koneksionisme menyatakan, bahwa

Jurnal Pendidikan Agama Islam (Journal of Islamic Education Studies)

Volume 5 Nomor 2 (2017)

ISSN(p) 2089-1946\& ISSN(e) 2527-4511

Hal. 334 - 338 
pendidikan Islam juga mengemukanan metode yang berbeda, di antaranya: metode al-Uswah (keteladanan), metode pembiasaan, metode kisah, metode nasihat, metode targhib wa tarhib, metode tadarruj wa tikrari. Sedangakan metode yang diterapkan dalam pembelajaran dalam membangun etika dan kepribadian di lembaga pendidikan Islam di antaranya; safari ramadhan, salat berjamaah, istighasah dan tahlil, seni Islami, kepramukaan, silaturahim dan bakti sosial.

Tiga desain metode pembelajaran yang dikemukakan oleh pakar psikologi pendidikan, pakar psikologi Islam dan metode yang dilakukan oleh lembaga pendidikan Islam bisa digunakan dan dipilih untuk mengembangkan dan membangun etika dan kepribadian peserta didik, baik yang diajarkan di kelas/sekolah maupun yang dipaktikkan di luar kelas melalui guru-guru yang profesional dan terdidik.

\section{G. Kesimpulan}

belajar/pembelajaran dipengaruhi oleh stimulus dan respon. Eksperimen yang dilakukan terhadap hewan dan manusia tentang cara memenuhi kebutuhan hidup yang di dalamnya juga kebutuhan akan belajar mengantarkan pada satu kesimpulan, bahwa belajar akan efektif jika hal-hal yang akan dipelajari merupakan kebutuhan hidup bagi orang yang belajar. b) Classical Conditioning (Ivan Pavlov). Teori Classical Conditioning atau pembiasaan klasik ditemukan oleh Ivan Pavlov dengan melalui berbagai eksperimen yang menyatakan, bahwa belajar adalah proses perubahan yang ditandai dengan adanya hubungan antara stimulus dan respon. Kegiatan pembelajaran di kelas stimulus biasanya dilakukan oleh guru dengan berbagai metode yang efektif, sedangkan respon yang dihasilkan adalah perubahan prilaku peserta didik yang menangkap stimulus tersebut dalam memori pikirannya dan diwujudkan dengan tindakan. Operant Conditioning (Frederic Skinner). c) Teori Operant Conditioning (pembiasaan prilaku) menyatakan, bahwa tingkak laku itu terbentuk oleh konsekwensikonsekwensi yang ditimbulkan oleh tingkah laku itu sendiri. Operant adalah tingkah laku yang membawa efek terhadap lingkungan di mana manusia tinggal. Ini artinya tingkah laku manusia itu harus dibiasakan karena membawa pengaruh bagi lingkungan dan kehidupannya. d) Contiguous Conditioning (Edwin R. Guthrie). Teori ini diartikan sebagaai teori belajar pembiasaan asosiasi dekat yaitu teori belajar yang mengasumsikan terjadinya peristiwa belajar berdasarkan kedekatan hubungan antara stimulus dan respon yang relevan (gurumurid). Menurut teori ini, bahwa apa yang dipelajari seorang siswa adalah reaksi atau respon yang ditimbulkan oleh stimulus (guru). e) Social Learning Theory (Albert Bandura). Teori ini menyatakan, bahwa tingkah laku manusia disebabkan reaksi yang timbul akibat interaksi antara lingkungan dan manusia itu sendiri. Prinsip dasar teori ini adalah perubahan prilaku manusia (murid) dalam kegiatan belajar bisa dengan cara peniruan (imitation) dan penyajian contoh prilaku (modeling). menurut teori ini siswa mampu merubah prilakunya sendiri dengan carai meniru apa yang ada di lingkungannya, baik lingkungan keluarga, lingkungan sekolah dan lingkungan masyarakat. Baca Muhibbin Syah, Psiklogi Belajar (Jakarta: Rajawali Press, 2009), 92-106. 
Membangun etika dan kepribadian dapat dilakukan dengan psikologi qur'ani, yaitu pemahaman mengenai psikologi/jiwa/ilmu jiwa yang bersumber dari al-Qur'an melalui kata; al-Nafs, al-Lubb, al-fu'ad, al-Hilm, al-Hijr, al-Nuhyah, al-Shu'ur, al-Ruh, al-Aql, al-Qalb. Al-Nafs merupakan komponen dasar manusia yang berwujud immateri yang berpotensi baik dan buruk. Nafs berfungsi mengarahkan manusia untuk berperilaku emosional atau lemah lembut. $A l-L u b b$ merupakan kemampuan yang melekat pada diri manusia untuk membedakan baik buruk dengan bukti rasional. Al-Fu'ad adalah kemampuan yang dimiliki manusia untuk mengendalikan diri. Al-Hilm merupakan potensi manusia yang mampu bersikap tenang dalam menyikapi segala sesuatu. Al-Hijr dan Al-Nuhyah adalah daya kemampuan nalar yang berfungsi membedakan antara baik dan buruk. Al-Syu'ur adalah aspek rohani manusia yang memungkinkan manusia dapat berfikir dan bernalar. Al-Ruh merupakan sesuatu yang dapat mengarahkan perilaku dan perbuatan manusia. Al-Aql merupakan kemampuan untuk memahami, menganalisa dan menyimpulkan serta dorongan moral yang disertai dengan kematangan berfikir. Al-Qalb merupakan daya nalar opini, kecerdasan praktis dan kecakapan untuk memecahkan suatu masalah. Implementasi Psikologi Qur'ani yang ditemukan melalui al-Qur'an kemudian diintegrasikan dengan metode pembelajaran psikologi yang dikemukakan oleh: (1) Pakar psikologi; Connectionism theory, Classical Conditioning, Operant Coditioning, Contiguous Conditioning, Cogitive theory dan Social Learning Theory; (2) Pakar psikologi Islam; metode al-Uswah (keteladanan), metode pembiasaan, metode kisah, metode nasihat, metode targhib wa tarhib, metode tadarruj wa tikrari; (3) Metode yang sudah dilakukan di lembaga pendidikan Islam; safari ramadhan, salat berjamaah, istighasah dan tahlil, seni Islami, kepramukaan, silaturahim dan bakti sosial.

\section{H. Referensi}

Abdurrahman, Muhammad. Rekonstruksi atas Moralitas Pendidikan. Yogyakarta: Primasophie, 2003.

Ahmadi, Abu. Psikologi Belajar. Jakarta: Rineka Cipta, 2013.

Aly, Noer. Ilmu Pendidikan Islam. Jakarta: Logos Wacana Ilmu, 1999.

Anderson, Orin and Krathwohl, David R. A Taxonomi for Learning; Teaching and Assassing, A Revision of Bloom's Taxonomi of Educational Objectives. New York: Longman Press, 2001.

Attas (al), Naquib. Islam dan Secularisme. Terj. Karsidjo. Bandung: Pustaka, 1981.

Banna (al), Hasan. Majmū' Al-Rasail al-Imām as-Syahīd Hasan Al-Bannā. Kairo: Dar al-Da'wah, $141 \mathrm{H}$. 
Baqi (al), Fuad Abd. Mu'jam al-Mufahras li alfâd al-Qur'an. Kairo: Dār al-Fikr, 1992.

Bloom, Benyamin S. Taksonomy of Educational Objectives; The Clasification of Educational Goals, Handbook 1 Cognitive Domain. London: Longman Group Ltd, 1979.

Farmawi (al), Abd al Hayy. Al-Bidayah Fi al-Tafsir al-Maudhu'i. Mesir: Maktabah al-Jumhuriyah, 1977.

Ghazali (al). Ihyā', 'Ulūm al-Dīn, Juz III,(Beirut, Dār al-Kutūb al-'Ilmiyah, t.t.

Ibrahim, Ismail. Mu'jām alfâd wa a'lām al- Quraniyah, Juz II. Kairo: Dâr al-Fikr alArabi, 1968, Cet. 2.

Jamali (al), Muhammad Fadil. Al-Falsafah al-Tarbiyyah fi al-Qur'an. Beirut: Dār alKitāb al-Jadid, 1966.

Khaldun, Ibnu. Al-Mukaddimah Ibn Khaldun, Terj. Thoha. Jakarta: Pustaka Firdaus, 2001.

Krippendorff, Klaas. Content Analysis, An Introduction to Its Theory and Methodology. Terj. Farid Wajidi. Jakarta: Raja Grafindo, 1993.

Ma’luf, L. Kamus al-Munjid. Beirut: Dār al-Mashrīq, 1986.

Miskawaih, Ibnu. Tahdzib al-Akhlaq, terj. Helmi Hidayat. Bandung: Mizan, 1994.

Muchlas, Imam. Himpunan Orasi Ilmiah Pengukuhan Guru Besar IAIN Sunan Ampel. Surabaya: IAIN Sunan Ampel Press, 2004.

Muhadjir, Noeng. Ilmu Pendidikan dan Perubahan Sosial. Yogyakarta: Rakesarasin, 1987.

Mursa, Muhammad Munir. Al-Tarbiyah al-Islamiyyah: Ushuluhā wa Tathawwuruhā fî̀ al-Bilād al-'Arabiyyah. Kairo: 'Alam al-Kutūb, 1977.

Nahlawi (al), Abd Rahman. Usūs al-Tarbiyyah wa al-Turūq al-Tadrīsuhā. Damaskus: Dār al-Fikr, tt.

Nasir, Ridlwan. Memahami al-Qur'an Perspektif Baru Tafsir Muqarrin. Surabaya: Indra Media, 2003.

Nata, Abudin. Akhlak Tasawuf. Jakarta: Raja Grafindo Persada, 1997.

Pemikiran Para Tokoh Pendidikan Islam; Suatu Kajian Filsafat Pendidikan Islam. Jakarta: Raja Grafindo Persada, 2003.

Nggermanto, Agus Quantum Quotient. Bandung: Nuansa, 2001. 
Ah. Zakki Fuad, Jauharoti Alfin, Ahmad Munjin Nasih

Poerwadarminta, W.J.S. Kamus Umum Bahasa Indonesia. Jakarta: Balai Pustaka, 1993.

Purwanto, Ngalim. Psikologi Pendidikan. Bandung: Rosdakarya, 1996.

Qurtubi (al), Abi Abdullah Muhammad bin Ahmad. Al-jamî' al- Ahkâm al-Qur'an, Juz II. Kairo: Dār Kutūb al-Arabī, 1967.

Quthb, Muhammad. Sistem Pendidikan Islam. Bandung: al-Ma'arif, 1993.

Rahmān, Faẓlur. Indeks al-Qur'an. Jakarta: Amzah, 2009.

Ridha, Jawwad. Tiga Aliran Utama Teori Pendidikan Islam. Yogyakarta: Tiara Wacana, 2002.

Said. Etika Masyarakat Indonesia. Jakarta: Pradnya Paramita, 1976.

Salam, Burhanuddin. Etika Individual; Pola Dasar Filsafat Moral. Jakarta: Rineka Cipta, 2000.

Shihab, M. Quraish. Wawasan al-Qur'an: Tafsir Maudhu'i atas Pelbagai Persoalan Umat. Bandung: Mizan, 1998.

Software Maktabah al-Shamilah; Akbar Mausu'ah al-Islamiyyah, Ihdhar Thani.

Software The Holly Qur'an versi 7.10, Harf information Tecnology tahun 2000 M.

Subrata, Hadi. Mengembangkan Kepribadian Anak Balita. Jakarta: Gunung Muria, 1997.

Syah, Muhibbin. Psiklogi Belajar. Jakarta: Rajawali Press, 2009.

Syaibany (al), Omar Toumy. Falsafah al-Tarbiyyah al-Islämiyyah, Terj. Hasan Langgulung. Jakarta: Bulan Bintang, tt.

Tabarì (al), Ja'far Muhammad bin Jarìr. Tafsìr at-Ṭabarí, Juz II. Beirut: Dār al-Fikr, 1978.

Tobroni dan Arifin, Syamsul. Islam Pluralisme Budaya dan Politik. Yogyakarta: SiPress, 1994.

Ulwan, Abdullah Nasih. Tarbiyah al-Aulād fi al-Islām. Beirut: Dār as-Salām, t. t.

Ya’qub, Hamzah. Etika Islam. Bandung: Rineka Cipta, 1983.

Jurnal Pendidikan Agama Islam (Journal of Islamic Education Studies)

Volume 5 Nomor 2 (2017)

ISSN(p) 2089-1946\& ISSN(e) 2527-4511

Hal. 338 - 338 